\title{
Geochemical mapping of potentially hazardous elements in surface waters and stream sediments of the Quadrilátero Ferrífero, Brazil
}

\author{
Raphael de Vicq Ferreira da Costa ${ }^{1 *}$ \\ Jörg Matschullat ${ }^{2}$ \\ Mariangela Garcia Praça Leite \\ Hermínio Arias Nalini Junior ${ }^{1}$ \\ Lucas Pereira Leão ${ }^{1}$ \\ ${ }^{1}$ Post-Graduate Program in Crustal Evolution \\ and Natural Resources \\ Geology Department \\ Federal University of Ouro Preto \\ Morro do Cruzeiro s/n Bauxita \\ Ouro Preto, Minas Gerais, Brazi \\ 35.400-000 \\ ${ }^{2}$ Interdisciplinary Environmental Research \\ Centre \\ TU Bergakademie Freiberg \\ Brennhausgasse 14 \\ 09599 Freiberg, Germany \\ ${ }^{*}$ Corresponding author \\ raphaelvicq@gmail.com
}

\section{RESUMO}

O mapeamento geoquímico e a determinação das concentrações dos valores de referências de elementos potencialmente perigosos no ambiente vêm obtendo uma crescente relevância nos últimos anos. A necessidade de conhecer dados geoquímicos regionais, bem como a alocação espacial de áreas com concentrações de elementos anômalos e as chances de identificar suas principais fontes motivam o interesse. Aqui, resultados de um exercício de mapeamento geoquímico e derivados de valores de referência relacionados são apresentados. Foram coletadas 541 amostras de sedimentos e águas superficiais em todo o Quadrilátero Ferrífero (QF), Brasil, com uma densidade de 1 amostra por $13 \mathrm{~km}^{2}$. Para confecção dos mapas geoquímicos foi utilizada a técnica de interpolação denominada inverso da distância ponderada (IDW) e para distinguir os valores considerados normais das anomalias, foi adotada a técnica de separação por faixas de concentração, na qual as anomalias são definidas pela regra do "boxplot" Upper Inner Fence (UIF). Os resultados demonstram que mais de $70 \%$ da área do QF apresenta faixas de concentração relacionada aos valores do background geogênico para os elementos estudados. Cerca de $20 \%$ da área representam anomalias positivas, provavelmente relacionadas tanto a tipos de rochas próximas à superfície quanto à interferência humana. Anomalias antropogênicas distintas, notadamente das atividades de mineração, são identificadas em 5\% a $10 \%$ de todas as amostras. Esta primeira amostragem feita no QF permitiu delinear um controle efetivo da litologia sobre a composição química dos sedimentos, estabelecer valores de referência para as principais bacias e demonstrar quais comunidades, cidades e bacias que estão expostas a riscos ambientais e por isso necessitam ser protegidas.

Palavras-Chave: Geoquímica Ambiental, Valores de referência, Sedimentos, Águas superficiais, Mapeamento Geoquímico, Quadrilátero Ferrífero, Brasil

\section{ABSTRACT}

Geochemical mapping and the determination of baseline concentrations of potentially hazardous elements in the environment receive increasing attention. The need to know regional geochemical background data as well as the spatial allocation of areas with anomalous element concentrations and chances to identify their major sources motivate the interest. Here, results from a geochemical mapping exercise and derived related baseline values are presented. 541 stream sediment and surface waters samples have been collected across the Iron Quadrangle (IQ), Brazil, with a density of 1 sample per $13 \mathrm{~km}^{2}$. Geochemical maps were compiled using the inverse distance weighted (IDW) interpolation method. "Normal" background concentrations were distinguished from anomalies with the separation-by-concentrationrange technique, where positive anomalies were defined by the "boxplot" Upper Inner Fence (UIF) rule. The results demonstrate that more than $70 \%$ of the IQ area shows geogenic background concentration ranges for the elements studied. About $20 \%$ of the area represent positive anomalies, likely related to both near surface rock types and to human interference. Distinct anthropogenic anomalies, notably from mining activities are identified in 5$10 \%$ of all samples. This first sampling in the IQ allows delineation of the 
role of lithology on the elemental composition of stream sediments, and to establish baseline values for the main river basins - thus pinpointing localities, cities and fluvial basins that are exposed to environmental risks and need to be protected.

Keywords: Environmental geochemistry, Background values, Sediments, Surface waters, Geochemical mapping, Iron Quadrangle, Brazil

\section{INTRODUCTION}

Geochemical mapping significantly contributes to the sustainability triad (environmental, social and economic development), since it enables the discovery of new areas for mineral exploration, highlights critical areas that may restrict certain types of land-use, provides regional background values that help in safeguarding population and environment, and supports directing environmental policies (Albanese et al. 2006; Caritat et al. 2007; Khalil et al. 2013; Kř́bek et al. 2014, Li et al. 2014; Reimann and Garret 2005). Therefore, geochemical mapping has gained increasing prominence in recent years, particularly in respect to environmental analyses (Smith et al. 2012).

Although the geological complexity of the Iron Quadrangle (IQ), Brazil already suggests a highly diverse geochemistry, this has never been studied in detail. Various publications reported high concentrations of potentially hazardous elements in water and sediments, which were often related to human activities, particularly to the long

\section{STUDY AREA}

The Iron Quadrangle (IQ) in south-east Brazil is one of the richest regions in the world regarding economic minerals, covering an area of approximately $7,000 \mathrm{~km}^{2}\left(19^{\circ} 45^{\prime}\right.$ to $20^{\circ} 30^{\prime} \mathrm{S}$ and $44^{\circ} 30^{\prime}$ to $\left.43^{\circ} 07^{\prime} \mathrm{W}\right)$. Its history of settlement and mineral exploration dates back to the last decades of the $17^{\text {th }}$ Century (Meneses et al. 2011). The region includes 35 municipalities from the central region of Minas Gerais state (Figure 1), with more than 4,135,000 inhabitants (IBGE 2010), accounting for $22 \%$ of the total state population.

The regional economy is based on mining and tourism with additional intense industrial activities, particularly in the steel industry and metallurgy. Important mining activities focus on iron ores and vast reserves of, e.g., gold, limestone, dolomite, bauxite, steatite, manganese, topaz, clay, etc., constituting one of the most important mineral production provinces in the country and the best known in geological terms (Nalini Jr. et al, (2009).

Mining is often seen as an inexhaustible source of sediment contamination by trace elements in mining history (Borba et al. , 2003, Costa 2007; Deschamps and Matschullat 2011; Matschullat et al. 2000a; Mendonça 2012; Parra et al. 2007, Varajão et al., 2010). These studies were scattered over various IQ sub-regions. However, some were of an environmental nature, others focused on mineral exploration; generalizations did not appear to be justifiable. Hitherto, no regional mapping studies exist that cover the entire IQ with its variety of rock types. To date, no reliable baseline values were available for the region so far.

To fill this gap, water and stream sediments have been collected to i) determine baseline values for the development of future environmental legislation, ii) detect risk areas with potentially hazardous elements, iii) establish concrete relationships between the different rock types and the concentrations of some major and minor elements and of $\mathrm{As}, \mathrm{Cd}, \mathrm{Cr}, \mathrm{Cu}, \mathrm{Ni}, \mathrm{Pb}$ and $\mathrm{Zn}$, and iv) contribute to distinguishing natural (geogenic) from anthropogenic anomalies.

rivers (Carranza 2009; Khalil et al. 2013; Kříbek et al. 2014). Many studies have been conducted on the accumulation of trace elements in river basins of mined areas in Europe, Asia, North America and Brazil. These studies have reported the elevated presence of various trace elements in water and stream sediments and related adverse environmental effects (Albanese et al. 2006; Almeida 2005; Ranasinghe et al. 2009; Thornton 2012). A similar situation can be studied in the $\mathrm{IQ}$, where various trace elements, e.g., $\mathrm{As}, \mathrm{Cd}, \mathrm{Cr}$, $\mathrm{Ni}, \mathrm{Pb}$, and $\mathrm{Zn}$, occur in partly excessive concentrations in both waters and in stream sediments (Costa 2007; Mendes 2007; Parra et al. 2007; Pereira et al. 2007, Deschamps and Matschullat 2011; Mendonça 2012; Varajão et al., 2010.

Three major lithostratigraphic units characterize the regional geology: (1) Archaean to Proterozoic granite-gneiss basement, (2) Archaean greenstone belt, and (3) Proterozoic supracrustal sequence. 
The Bonfim, Santa Rita, Caeté, Belo Horizonte, Santa Bárbara and Bação granitegneiss metamorphic complexes represent the crystalline base of the region, composed of polydeformed gneissic rocks of tonalitic composition and of granite, granodiorite, mafic and ultramafic intrusions, this granite-gneiss terrain consists of tonalite-trondhjemite-granodiorite (TTG) formed between 3380 and $2900 \mathrm{Ma}$ (Teixeira et al. 2000).

The Das Velhas River Supergroup comprises the Nova Lima and Maquiné groups. The Nova Lima group has: (1) a volcanic basal unit varying from tholeiitic to komatiite, associated with large numbers of sedimentary rocks, (2) superimposed volcanic unit with associated felsic volcanism, and (3) a superior clastic unit. Carneiro (1992), named the interval of 2.78 to $2.80 \mathrm{Ga}$, das Velhas River Orogenic Event, in which there was the rework of the Archaean sialic crust, intrusion of tonalitic bodies and felsic volcanism of the Velhas River greenstone belt. The clastic sedimentary rocks of the upper unit of the greenstone belt are predominantly sequences of greywacke-argillites, with evidences of the significant contribution of the felsic volcanic rocks of the greenstone belt and the reworking of the Archaean crust. The sandstones and conglomerates of Maquiné Group overlap the Nova Lima Group along an angular discordance (Baltazar and Zuchetti 2007).

The Minas Supergroup and Itacolomi Group constitute the supracrustal proterozoic sequences. The distribution of the Minas Supergroup defines the geometric contour of the IQ, whose boundaries are defined by large folds of the syncline type.

The Minas Supergroup represents a continental margin sequence, with sedimentation ages varying between 2580 and $2050 \mathrm{Ma}$ (Renger et al. 1994). From the base to the top it is divided into the Caraça, Itabira, Piracicaba and Sabará groups. The

\section{MATERIALS AND METHODS}

\subsection{SAMPLING}

The choice of the sampling points was based on the methodology proposed by Bolviken et al. (2004), with water and sediment being collected at the mouths of $3^{\text {rd }}$ order basins. These locations were determined using the ArcGIS 9.2 software with hypsometric, topographic and hydrographic maps of the region on a 1:25,000 scale, provided by the Institute of Water Management of the State of Minas Gerais (IGAM) and Geological Survey of Brazil (CPRM).

From the determination of the points, 541 surface water and stream sediments were sampled
Caraça Group is composed of sandstones and conglomerates, and represents the rift stage of the basin, whose maximum deposition age was $2.6 \mathrm{Ga}$ (Machado et al. 1996). The Itabira Group consists of banded iron formations (BIF) present in the Cauê Formation with $2.65 \mathrm{Ga}$ (Cabral et al. 2012) and carbonate rocks in the Gandarela Formation, 2,42 (Babinski et al. 1995). The Piracicaba Group is composed of ferruginous quartzite and schists, conglomerates with BIF pebbles and carbonaceous phyllites that have been deposited in a shallow to deep marine environment. The Sabará Group consists of sin-orogenic deposits, deposited in a foreland-type basin, thus marking the tectonic inversion of the Minas Basin (Renger et al. 1994, Alkmin and Marshak 1998), with a maximum deposition age of $2.1 \mathrm{Ga}$ (Machado et al. 1996).

The Itacolomi Group is composed of a sequence of metamorphosed supracrustal rocks that cover the Minas Supergroup, consisting of quartzites, phyllites and meta-conglomerates, locally crossed by basic rock dikes. Polymorphic conglomerates, serictic quartzites and pellets to the Itacolomi Group, which were accumulated during the collapse phase after the Paleoproterozoic Transamazonium $2.10 \quad \mathrm{Ga}$ orogeny (Alkmim and Marshak, 1998; Farina et al., 2015). Finally, Cenozoic coverings are present filling small basins in the IQ region.

The IQ yields the headwaters of two major Brazilian river basins, the Doce and the São Francisco. These are fed by the sub-basins Das Velhas River, Paraopeba River (both draining into the São Francisco River), and Conceição River; Piracicaba River; Carmo River, Gualaxo do Sul and Gualaxo do Norte Rivers (draining into the Doce River). All sub-basins have been exposed to anthropogenic interference from the beginning of the settlement of Minas Gerais in the $17^{\text {th }}$ century.

between March 2011 and October 2012 throughout the entire IQ $\left(7,000 \mathrm{~km}^{2}\right)$, providing a sampling density of 1 sample per $13 \mathrm{~km}^{2}$ (Figure. 1).

All sediments were collected along a 300 to $500 \mathrm{~m}$ long river stretch with nine subsamples each to cover distinct patterns of the fluvial geomorphology (riffles, pools and transition). In every morphology, samples were taken from the right and left bank area as well as the center of the channel at a minimum distance of $\geq 50 \mathrm{~cm}$ from the riverbank, always seeking to avoid the 
collection of highly irregularly deposited organic matter. Subsamples were mixed to obtain a representative composite sample of the stretch, following the protocol in Salminen et al. (2005). After complete homogenization, $500 \mathrm{~g}$ samples were packed and stored in plastic bags (PE) as recommended by the United States Environmental Protection Agency (USEPA 2001).

The water samples were always collected together with the stream sediments samples at each sampling point, Water samples were collected at the center of each stretch, filtered with the aid of a cellulose acetate membrane (Millipore $0.45 \mu \mathrm{m})$ and acidified with three drops of nitric acid (USEPA, 2000).

To complement the field information, $\mathrm{pH}-$ values, electrical conductivity (EC in $\mu \mathrm{S} \mathrm{cm}^{-1}$ ), total dissolved solids (TDS in $\mathrm{mg} \mathrm{kg}^{-1}$ ), redox potential $($ Eh in $\mathrm{mV})$, temperature $\left({ }^{\circ} \mathrm{C}\right)$, dissolved oxygen $\left(\mathrm{O}_{2}\right.$ in $\left.\mathrm{mg} \mathrm{L}^{-1}\right)$ and turbidity $(\mathrm{NTU})$ were determined at each sampling point, using a multiparameter probe (Ultrameter II, Myron L Company) and a turbidimeter (Hanna model HI 93703).

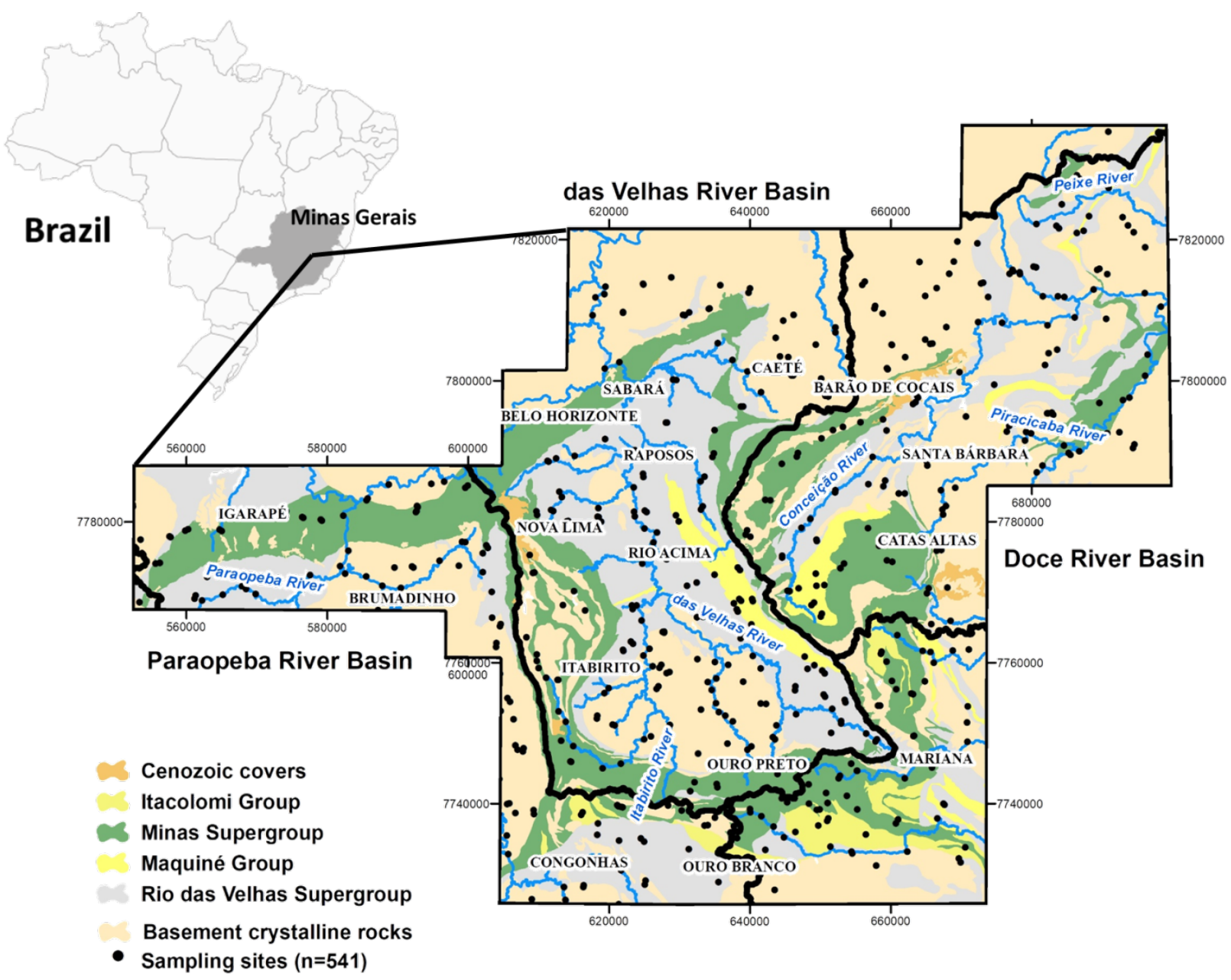

Figure 1

Simplified geological map of the IQ region, showing the sampling sites and the distribution of basement crystalline rocks, Minas Supergroup, Rio das Velhas Supergroup, Maquiné Group, Itacolomi Group,Cenozoic Covers and the major river basins.

\subsection{CHEMICAL ANALYSES AND QUALITY CONTROL}

The sediment samples were dried at room temperature, homogenised and sieved $(\leq 63 \mu \mathrm{m})$. One gram of the grain size fraction $<63 \mu \mathrm{m}$ was used per sample for the subsequent digestion process with aqua regia $\left(\mathrm{HCl}\right.$ to $\left.\mathrm{HNO}_{3}, 3: 1\right)$ at the Geochemical Laboratory of the Federal University of Ouro Preto (UFOP). After forming sediment "pulp" with some milli-Q water, $7.0 \mathrm{~mL}$ of concentrated $\mathrm{HCl}$ and $2.3 \mathrm{~mL}$ of concentrated $\mathrm{HNO}_{3}$ (both Merck p.a.) were added. These samples were allowed to rest for 16 hours under a fume hood at room temperature. Thereafter, the beakers were heated (hot plate) to $100 \pm 5^{\circ} \mathrm{C}$ for two hours for volume reduction, then cooled to 
room temperature and filtered through $0.45 \mu \mathrm{m}$ pore filter paper. The solution was then diluted with Milli-Q water in a volumetric flask to 100 $\mathrm{mL}$ total volume. To evaluate the accuracy of analyses, blank samples were produced at every tenth sample, and $10 \%$ of the samples were done in duplicate. The results were additionally controlled for accuracy using certified reference material (LKSD-01, CCNRP, Canada). Recovery rates were always between 93 and $107 \%$ and are presented in Table 1.

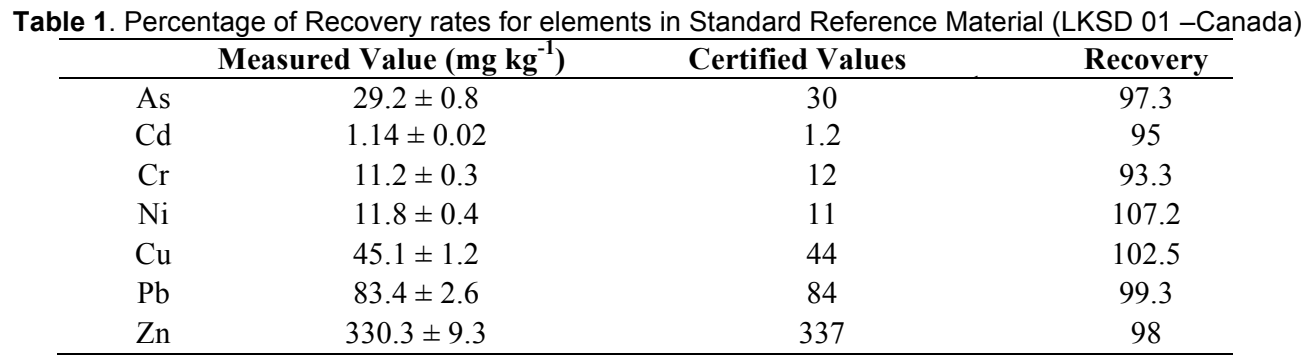

Digestion with aqua regia is called pseudototal digestion and allows for the extraction of elements associated with the non-silicatic fraction (although it cannot dissolve various oxides either; e.g., $\mathrm{Al}_{2} \mathrm{O}_{3}, \mathrm{TiO}_{2}$ ). The obtained, relatively mobile, fraction is of greater environmental interest, since it represents most oxides, sulfides, clay minerals and elements bonded to organic matter (Albanese et al. 2006; Ferreira et al. 2001). This procedure was chosen because it allows assessing the maximum amount of elements that can be released from sediments under acidic conditions; indicating the maximum environmental risk of each region (e.g., under the influence of acid mine drainage).

The sample solutions were analyzed by Inductively Coupled Plasma-Atomic Emission
Spectrometry (ICP-AES, Spectro Ciros CCD) for $\mathrm{Al}, \mathrm{As}, \mathrm{Ca}, \mathrm{Cd}, \mathrm{Co}, \mathrm{Cr}, \mathrm{Cu}, \mathrm{Fe}, \mathrm{K}, \mathrm{Mg}, \mathrm{Mn}, \mathrm{Na}$, $\mathrm{Ni}, \mathrm{Pb}, \mathrm{Ti}$ and $\mathrm{Zn}$-concentrations. Detection limits are provided in Table 2. Concentrations particularly of $\mathrm{Al}, \mathrm{Cr}$, and $\mathrm{Ti}$ may deviate significantly from true total concentrations as determined by techniques such as with wavelength-dispersive X-ray fluorescence (WDXRF) spectrometry (Table 3).

The water samples were preserved under refrigeration and then analyzed by Inductively Coupled Plasma-Atomic Emission Spectrometry (ICP-AES, Spectro Ciros CCD) for Al, As, Ca, $\mathrm{Cd}, \mathrm{Cr}, \mathrm{Cu}, \mathrm{Fe}, \mathrm{K}, \mathrm{Mg}, \mathrm{Mn}, \mathrm{Na}, \mathrm{Ni}, \mathrm{Pb}, \mathrm{Ti}$ and Zn-concentrations, at the Laboratory of Geochemistry of the Federal University of Ouro Preto. Detection limits are provided in Table 2.

Table 2. Detection limits for major, minor and trace elements determined by ICP-AES

\begin{tabular}{ccc}
\hline Element & Detection Limit for Stream Sediments $\left(\mathrm{mg} \mathrm{kg}^{-1}\right)$ & Detection Limit for Water $\left(\mu \mathrm{g} \mathrm{kg}^{-1}\right)$ \\
\hline $\mathbf{A l}$ & 2.6 & 7.3 \\
$\mathbf{A s}$ & 1.6 & 57.7 \\
$\mathbf{C a}$ & 1.0 & 0.0002 \\
$\mathbf{C d}$ & 0.4 & 6.2 \\
$\mathbf{C r}$ & 0.2 & 5.3 \\
$\mathbf{C u}$ & 0.3 & 3.6 \\
$\mathbf{F e}$ & 0.8 & 5.6 \\
$\mathbf{K}$ & 2.1 & 0.00007 \\
$\mathbf{M g}$ & 0.1 & 0.0004 \\
$\mathbf{M n}$ & 0.1 & 1.2 \\
$\mathbf{N i}$ & 0.6 & 20 \\
$\mathbf{P b}$ & 1.0 & 7.2 \\
$\mathbf{T i}$ & 0.6 & 3.9 \\
$\mathbf{Z n}$ & 0.1 & 3.5 \\
\hline
\end{tabular}

\subsection{GEOCHEMICAL MAPS}

The database obtained from the surface water and stream sediment samples was used to prepare iso-value maps showing the distribution of the potentially hazardous elements in the area. The geo-statistical interpolation tool IDW (inverse distance weighting) was applied in ArcGis (De Vivo et al. 2003), choosing 12 points as nearest neighbours (Albanese et al. 2006; Bai et al. 2009). 


\subsection{BASELINE VALUES}

In order to distinguish normal geochemical background concentrations from anomalies, in both (surface waters and stream sediments), the separation-by-concentration-range technique was adopted (Reimann and Garret, 2005; Caritat et al. 2007; Carranza 2009), where anomalies were defined by the "boxplot" Upper Inner Fence (UIF). To order the data and designing the graphic were used the statistical softwares EXCEL and Minitab. The boxplot divides the ordered values of the data into four equal parts, from the definition of the median (displayed as a line in the box - Figure. 2) and then the quartiles Q1 (25\%) and Q3 (75\%). The third quartile (Q3) is considered as the background.
These upper and lower quartiles define the central box, which thus contains approximately $50 \%$ of the data. The upper inner fence (UIF) is defined as the box extended by 1.5 times the length of the box towards the maximum and the minimum and was considered as the high baseline. The upper and lower "whiskers" are then drawn from each end of the box to the farthest observation inside the inner fence, and the results that are above the UIF are considered outliers, called anomalies. While somewhat simplistic, the approach is comparable with other statistics-based alternatives (e.g., Matschullat et al. 2000b).

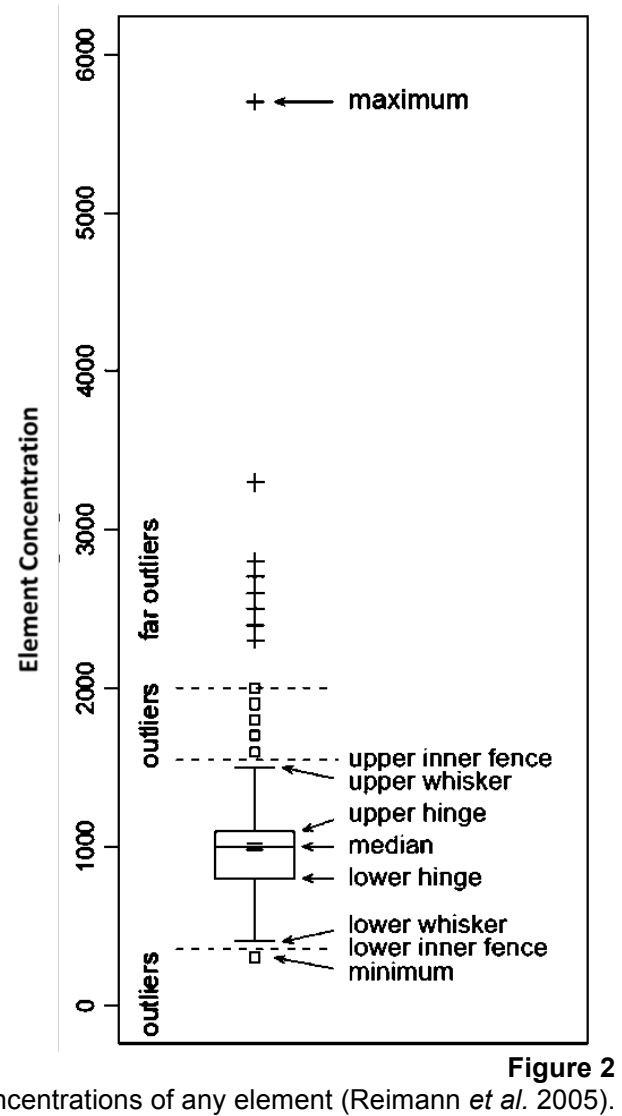

\section{RESULTS AND DISCUSSION}

The sediment results (median values) were compared with recent geochemical data (Table 3) from European stream sediments (Salminen et al. 2005) and the National Geochemical Survey of Australia (Caritat and Cooper, 2011), a nationwide mapping of Portugal (Ferreira et al. 2001) and of the Campania region in Italy (Albanese et al. 2006), with southern China (Cheng et al. 2014) and west-central Nigeria
(Lapworth et al. 2012). It is observed that the values of $\mathrm{Fe}$ in IQ are notably higher than in all other regions surveyed, $\mathrm{Mn}$ also shows high values when compared with Europe, Australia and Portugal, but similar to those found in Italy, China and Nigeria. Aluminium, $\mathrm{Cr}$ and Ti-values should not be directly compared, since our digestion method cannot deliver total concentrations for these elements. 
Table 3. Descriptive statistics for the 541 stream sediment samples from the entire Iron Quadrangle in comparison with data from Australia (1187 samples), Portugal (653 samples), Italy (2389 samples), China (5244 samples), Europe (845 samples), and Nigeria'(1659 samples) (Africa). Numbers rounded for clarity

\begin{tabular}{|c|c|c|c|c|c|c|c|c|c|c|c|c|c|}
\hline & Unit & Min & Max & Mean & Median & Q1 & Q3 & EUR* & AUS** & $\mathbf{P T}^{\#}$ & Italy & $\mathbf{C N} * * *$ & Nigeria \\
\hline $\mathrm{Al}$ & wt.- $\%$ & $4.0 \times 10^{-3}$ & 9.4 & 2.3 & 1.7 & 0.95 & 3.4 & 5.5 & 1.5 & 1.6 & 1.5 & 7.3 & 6.0 \\
\hline $\mathrm{Fe}$ & wt.-\% & $7.110^{-3}$ & 62.3 & 13.9 & 10.5 & 5.5 & 19.6 & 2.0 & 2.3 & 2.5 & 2.1 & 3.4 & 2.8 \\
\hline $\mathrm{Ca}$ & wt.- $\%$ & $3.7 \times 10^{-4}$ & 2.2 & 0.14 & 0.1 & 0.03 & 1.3 & 1.7 & 0.3 & 0.2 & 6.4 & 0.7 & 0.5 \\
\hline $\mathrm{Mg}$ & wt.- $\%$ & $1.0 \times 10^{-5}$ & 1.6 & 0.10 & 0.05 & 0.03 & 0.11 & 0.7 & 0.3 & 0.4 & 0.6 & 0.6 & 0.2 \\
\hline $\mathrm{K}$ & wt.- $\%$ & $1.3 \times 10^{-5}$ & 0.6 & 0.05 & 0.03 & 0.01 & 0.06 & 1.7 & 0.2 & 0.1 & 0.3 & 1.9 & 1.7 \\
\hline $\mathrm{Ti}$ & wt.- $\%$ & $5.6 \times 10^{-5}$ & 0.3 & 0.06 & 0.04 & 0.02 & 0.07 & 0.4 & n.d & n.d & 0.02 & 0.5 & 0.9 \\
\hline As & $\mathrm{mg} \mathrm{kg}^{-1}$ & 1.6 & 1,690 & 18.1 & 3.6 & 1.6 & 6.1 & 6.0 & 2.1 & 9.0 & 5.7 & 12.5 & 1.06 \\
\hline $\mathrm{Cd}$ & $\mathrm{mg} \mathrm{kg}^{-1}$ & 0.4 & 23 & 1.1 & 0.4 & 0.4 & 0.9 & 0.28 & 0.05 & n.d & 0.2 & 219 & $<0.08$ \\
\hline $\mathrm{Cr}$ & $\mathrm{mg} \mathrm{kg}^{-1}$ & 0.2 & 2,580 & 133 & 74 & 34 & 128 & 21 & 29.4 & 23 & 19.9 & 70 & 56.8 \\
\hline $\mathrm{Cu}$ & $\mathrm{mg} \mathrm{kg}^{-1}$ & 0.3 & 233 & 23 & 17 & 8.7 & 33 & 14 & 16.5 & 22 & 30.3 & 25 & 14.0 \\
\hline Mn & $\mathrm{mg} \mathrm{kg}^{-1}$ & 0.1 & 28,210 & 1,580 & 780 & 360 & 1,770 & 452 & 387 & 411 & 811 & 739 & 649 \\
\hline $\mathrm{Ni}$ & $\mathrm{mg} \mathrm{kg}^{-1}$ & 0.7 & 680 & 38 & 18.5 & 8.1 & 43 & 16 & 13.8 & 19 & 21.2 & 29 & 14.7 \\
\hline $\mathrm{Pb}$ & $\mathrm{mg} \mathrm{kg}^{-1}$ & 1.0 & 107 & 23 & 21 & 13.7 & 32 & 14 & 10.5 & 19 & 22.4 & 31 & 30.5 \\
\hline $\mathrm{Zn}$ & $\mathrm{mg} \mathrm{kg}^{-1}$ & 1.6 & 340 & 51 & 47 & 35 & 60 & 60 & 37.3 & 74 & 70.8 & 81 & 47.0 \\
\hline
\end{tabular}

Note: All comparative data from other countries are median values. Q1: $1^{\text {st }}$ quartile; Q3: $3^{\text {rd }}$ quartile. EUR*: European stream sediment survey (Salminen et al. 2005) with Al, Ca, Mg, K, Ti, Cd, Co by WD-XRF. AUS**: National Geochemical Survey of Australia (TOS-Top Outlet Sediments, fraction $<75 \mu \mathrm{m}$, aqua regia, ICP-Mass Spectrometry explain in full first time used (ICPMS)) (Caritat and Cooper 2011). $\mathrm{PT}^{\#}=$ Portugal: low-density geochemical mapping (Ferreira et al. 2001). Italy: Campania Region (Albanese et al. 2006). CN***: geochemical mapping in Southern China (Cheng et al. 2014) with Al, Fe, Ca, Ti, Cr, Mn, Pb, Ni by XRF, other elements by ICP-MS. Nigeria: geochemical mapping in west-central Nigeria (Lapworth et al. 2012); data from total digestion ICP-MS and WD-XRF.

While arithmetic averages of $\mathrm{Fe}, \mathrm{As}, \mathrm{Cd}, \mathrm{Co}$, $\mathrm{Cr}, \mathrm{Mn}$ and Ni show relative enrichments in the IQ sediments reflecting mineralogical (lithological) anomalies associated with release from metal mining, the median values do not. This clearly points at the non-normally distributed data with specific positive anomalies. The high Feconcentrations relative to other countries reflect tropical weathering and iron enrichment processes. The plant nutrients $\mathrm{Ca}, \mathrm{Mg}$ and $\mathrm{K}$ show a strong relative depletion relative to other countries, typical for geologically and pedologically old soils and sediments in subtropical environments. The environmental mobility of these plant nutrients (Reimann and Caritat 1998), the very long weathering time (the youngest rocks are at least $2.1 \mathrm{Ga}$ old - Machado et al. 1996) and the climatological situation (subtropical) likely explains their difference compared to other regions of the world. This further corroborates our argument that regional backgrounds need to be established in order to derive truly area-representative anomalous values, rather than comparing local data with global or continental average values.

By contrast, from what was observed in stream sediments about the median values, the comparison of the median surface water results with the values from Europe (FOREGS, 2005) and the world (Ivanov 1996) showed notable differences, with $\mathrm{Fe}, \mathrm{Pb}, \mathrm{Mn}$ and $\mathrm{Zn}$ being markedly higher in stream waters in the IQ region (Table 4).
The iron median value (356) is 5.3 and 9 times higher than Europe and the world value, respectively, similar values were found for $\mathrm{Zn}$ (17 and 2.3 times higher) and $\mathrm{Mn}$ (7.5 and 10.5 times) respectively. However, it was lead (median 8.3) that presented high values, 92 times higher than the value for Europe and 277 times higher than world average stream water concentrations.

These results demonstrate that the IQ is an area very enriched with these elements, which occur due to the weathering processes observed in subtropical environments and the intense mining and steel industry activities present in the region.

Classified concentration ranges of the seven trace elements in stream sediments and waters, with all values exceeding the UIF being considered anomalies and values between Q3 $\left(75^{\text {th }}\right.$ percentile) and the UIF as 'high baseline', and values below Q3 as background, as well Limits for Drinking Water (Brazil Decree 2914, 2011) and reference values for sediment quality from the Canadian Council of Ministers of the Environment (CCME 2000), are presented in Table 5.

The sampling density allowed us to a) delineate the role of lithology on the elemental composition of the sediments, and b) establish well-defined behaviour pattern of elements for each rock type. This in turn permitted c) the detection of anthropogenic anomalies, which could be verified, e.g., for $\mathrm{Pb}$, near specific mining sites. 
Table 4. Descriptive statistics for the 541 water samples from the entire Iron Quadrangle in comparison with data from Europe (807 samples) and World (n.a). Numbers rounded for clarity

\begin{tabular}{cccccccccc}
\hline & Unit & Min & Max & Mean & Median & Q1 & Q3 & EUR* $^{*}$ & WORLD** \\
\hline $\mathrm{Al}$ & $\mu \mathrm{g} / \mathrm{L}$ & 7.3 & 16878 & 167.9 & 33.6 & 15.5 & 84.9 & 17.7 & 160 \\
$\mathrm{Fe}$ & $\mu \mathrm{g} / \mathrm{L}$ & 5.6 & 17446 & 574.8 & 356.8 & 153.2 & 716.4 & 67 & 40 \\
$\mathrm{Ca}$ & $\mathrm{mg} / \mathrm{L}$ & 0,20 & 2468 & 16,51 & 2,97 & 1,89 & 5,50 & 40.2 & 12 \\
$\mathrm{Mg}$ & $\mathrm{mg} / \mathrm{L}$ & 0,40 & 673 & 12,84 & 1,43 & 0,74 & 2,67 & 6.02 & 2.9 \\
$\mathrm{~K}$ & $\mathrm{mg} / \mathrm{L}$ & 0,07 & 1446 & 4,11 & 0,84 & 0,45 & 1,57 & 1.60 & 2.3 \\
$\mathrm{Ti}$ & $\mu \mathrm{g} / \mathrm{L}$ & 3.9 & 130 & 7.3 & 4.5 & 4.5 & 4.5 & 0.90 & 3 \\
$\mathrm{As}$ & $\mu \mathrm{g} / \mathrm{L}$ & 57.7 & 414 & 72.9 & 57.7 & 57.7 & 57.7 & 0.63 & 2 \\
$\mathrm{Cd}$ & $\mu \mathrm{g} / \mathrm{L}$ & 6.2 & 202 & 7.1 & 6.2 & 6.2 & 7.8 & 0.01 & 0.2 \\
$\mathrm{Cr}$ & $\mu \mathrm{g} / \mathrm{L}$ & 5.3 & 385.8 & 44.3 & 8.5 & 8.5 & 55.2 & 0.38 & 1 \\
$\mathrm{Cu}$ & $\mu \mathrm{g} / \mathrm{L}$ & 3,6 & 263 & 31,11 & 3,6 & 3,6 & 60,4 & 0.88 & 7 \\
$\mathrm{Mn}$ & $\mu \mathrm{g} / \mathrm{L}$ & 1,2 & 20296 & 247,7 & 105,7 & 49 & 269 & 15.9 & 10 \\
$\mathrm{Ni}$ & $\mu \mathrm{g} / \mathrm{L}$ & 20 & 264.7 & 32.2 & 23.4 & 20 & 38.4 & 1.91 & 2.5 \\
$\mathrm{~Pb}$ & $\mu \mathrm{g} / \mathrm{L}$ & 7.2 & 214.7 & 25.9 & 8.3 & 7.2 & 29.4 & 0.09 & 0.03 \\
$\mathrm{Zn}$ & $\mu \mathrm{g} / \mathrm{L}$ & 3,5 & 2198 & 112,6 & 46,5 & 22,9 & 83,1 & 2.68 & 20 \\
\hline
\end{tabular}

All comparative data for other areas of the world are median values. Q1: $1^{\text {st }}$ quartile; Q3: $3^{\text {rd }}$ quartile. EUR*: Data from European Surface Waters Survey; FOREGS (2005) Filtered $<0.45 \mu \mathrm{m}$. WORLD**: Data from Ivanov (1996) Filtered $<0.45 \mu \mathrm{m}$.

Table 5; Limits for Drinking Water (Brazil Decree 2914, 2011) and Intervention limits for potentially hazardous elements in stream sediments (CCME 2000); concentration ranges and classification of reference values for potentially toxic elements in the Iron Quadrangle for Surface Waters and Stream Sediments

\begin{tabular}{|c|c|c|c|c|c|c|c|c|}
\hline & Limit for & Surface Waters & Classification & Percentage & CCME & Stream & Classification & Percentage \\
\hline \multirow{3}{*}{ As } & \multirow{3}{*}{10} & $57.7-69.4$ & Background & $74 \%$ & \multirow{3}{*}{33} & $1.6-6.1$ & Background & $78 \%$ \\
\hline & & $>69.4-96.8$ & High Baseline & $17 \%$ & & $>6.1-12.8$ & High Baseline & $16 \%$ \\
\hline & & $>96.8$ & Anomaly & $9 \%$ & & $>12.8$ & Anomaly & $6 \%$ \\
\hline \multirow{4}{*}{$\mathrm{Cd}$} & \multirow{4}{*}{5} & $6.2-7.8$ & Background & $76 \%$ & \multirow{3}{*}{10} & $0.4-0.9$ & Background & $74 \%$ \\
\hline & & $>7.8-9.4$ & High Baseline & $14 \%$ & & $>0.9-1.8$ & High Baseline & $16 \%$ \\
\hline & & $>9.4$ & Anomaly & $10 \%$ & & $>1.8$ & Anomaly & $10 \%$ \\
\hline & & $8.5-55.2$ & Background & $73 \%$ & \multirow{3}{*}{111} & $34.2-128$ & Background & $73 \%$ \\
\hline \multirow[t]{2}{*}{$\mathrm{Cr}$} & \multirow[t]{2}{*}{50} & $>55.2-102$ & High Baseline & $18 \%$ & & $>128-269$ & High Baseline & $15 \%$ \\
\hline & & $>102$ & Anomaly & $9 \%$ & & $>269$ & Anomaly & $12 \%$ \\
\hline \multirow{4}{*}{$\mathrm{Cu}$} & \multirow{4}{*}{2000} & $3.6-60.4$ & Background & $74 \%$ & \multirow{3}{*}{114} & $8.7-33$ & Background & $72 \%$ \\
\hline & & $>60.4-117.2$ & High Baseline & $20 \%$ & & $>33-68$ & High Baseline & $24 \%$ \\
\hline & & $>117,2$ & Anomaly & $6 \%$ & & $>68$ & Anomaly & $4 \%$ \\
\hline & & $20-38.4$ & Background & $75 \%$ & \multirow{3}{*}{36} & $8.1-43$ & Background & $72 \%$ \\
\hline \multirow{3}{*}{$\mathrm{Ni}$} & \multirow[t]{3}{*}{70} & $>38.4-56.8$ & High Baseline & $17 \%$ & & $>43-96$ & High Baseline & $22 \%$ \\
\hline & & $>56.8$ & Anomaly & $8 \%$ & & $>96$ & Anomaly & $6 \%$ \\
\hline & & $7.2-29.4$ & Background & $76 \%$ & \multirow{3}{*}{250} & $13.7-32$ & Background & $78 \%$ \\
\hline \multirow[t]{3}{*}{$\mathrm{Pb}$} & \multirow[t]{3}{*}{10} & $>29.4-51.6$ & High Baseline & $19 \%$ & & $>32-59$ & High Baseline & $20 \%$ \\
\hline & & $>51.6$ & Anomaly & $5 \%$ & & $>59$ & Anomaly & $2 \%$ \\
\hline & & $23-83.6$ & Background & $68 \%$ & \multirow{3}{*}{80} & $34.8-60.0$ & Background & $74 \%$ \\
\hline \multirow[t]{2}{*}{$\mathrm{Zn}$} & & $>83.6-144.2$ & High Baseline & $22 \%$ & & $>60.0-98.0$ & High Baseline & $21 \%$ \\
\hline & & $>144.2$ & Anomaly & $10 \%$ & & $>98.0$ & Anomaly & $5 \%$ \\
\hline
\end{tabular}

*PEL: Probable Effect Level for aquatic life

\subsection{ARSENIC}

Seventy-eight percent of the stream sediment samples contained As-values of up to $6.1 \mathrm{mg} \mathrm{kg}^{-1}$, and can be defined as the regional background (Fig. 2a). An intermediate high baseline' concentration range with levels of $6.1 \mathrm{mg} \mathrm{kg}-1 \mathrm{up}$ to $12.8 \mathrm{mg} \mathrm{kg}-1$ characterises $16 \%$ of the sediments, that are closely related to schists (part of the Nova Lima Group and the Velhas Supergroup - Figures 1 and 2a). These are located in central IQ, mainly near the municipalities of
Ouro Preto, Itabirito, Rio Acima, Nova Lima and Caeté, all famous locations for primary gold deposits.

Within this area, segments of the drainage systems with anomalous sediment concentrations stand out, representing less than $6 \%$ of the dataset: Sixteen points show concentrations from 102 to $1,690 \mathrm{mg} \mathrm{kg}{ }^{-1}$, fourteen of which are situated in river basins, where more than $60 \%$ of the area is underlain by these rock types. These are located in 
areas with intense urbanization and mining activities. The significant As-presence in this lithotype is corroborated by its occurrence in arsenopyrite, loellingite, realgar and arseniferous pyrite and the local gold mineralization.

This relationship between lithology and metallogeny becomes prominently visible, when comparing two districts in the IQ that both represent schists. A) The municipalities of Nova Lima, Raposos and Caeté have seen intense gold exploration and mining during the $17^{\text {th }}$ to $19^{\text {th }}$ centuries with numerous evidence of extraction and beneficiation, including abandoned mines and waste piles.

Here, positive anomalies occur in 28 sub-

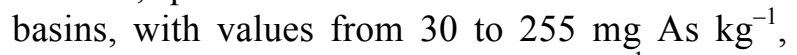
with one outlier of $1,690 \mathrm{mg} \mathrm{As} \mathrm{kg}^{-1}$. B). By contract, only six anomalies were observed in the Santa Bárbara district, where 19 streams, draining the same lithotype, were sampled in rural areas without mining and little urbanisation (concentrations from 19 to $93 \mathrm{mg} \mathrm{As} \mathrm{kg}{ }^{-1}$ ).

Anthropogenic influence and mineral exploration act as strong drivers for As-release. We found 52 points with As-concentrations above the Canadian intervention limit (aquatic life) for sediments; most of them located at rural and periurban localities in the Das Velhas River basin, with low-income and low-education populations, that often consumes fish from these rivers and is

\subsection{CADMIUM}

While most of the IQ yields relatively low stream sediment Cd-values, anomalies were found in all river basins (Figure 3a). The median $\mathrm{Cd}$ value throughout the IQ was $0.4 \mathrm{mg} \mathrm{kg}^{-1}$; basically equal to the detection limit and about four times above the upper crustal average $\left(0,09 \mathrm{mg} \mathrm{kg}^{-1}\right)$ (Salminen et al, 2004). Seventy-four percent of the sediment samples contained Cd-values below $0.9 \mathrm{mg} \mathrm{kg}^{-1}$, which may be considered a high baseline value. Only nine streams were found with values exceeding the CCME sediment guidelines; most of these in areas of much mining-related interference.

However, anomalous concentrations occurred in the Carmo river basin $\left(1.3\right.$ and $\left.13.5 \mathrm{mg} \mathrm{kg}^{-1}\right)$. In the Velhas River basin, 32 stream sites showed concentrations from 0.95 to $1.79 \mathrm{mg} \mathrm{kg}^{-1}$ and 20 sampling points yielded 1.80 to $14.7 \mathrm{mg} \mathrm{kg}^{-1}$. Most of these anomalies were observed in areas that drain schistose terranes; again parts of the Nova Lima Group rocks (Figures 1 and 3a).

The influence of these lithologies on the Cdconcentration is relevant because the related drainage basins showed median values and a Q3 supplied with the water from these sources and unaware of the potential related risks of high concentrations of As in the environment (Deschamps and Matschullat 2011).

The arsenic values in surface water ranged from $<57.7$ to $414 \mu \mathrm{g}$. $\mathrm{L}^{-1}$. Seventy sampling points $(13.7 \%)$, had values of arsenic above the quantification limit of $57.7 \mu \mathrm{g}$. $\mathrm{L}^{-1}$, which in this case was considered as the background value, because most of the sample points $(86.7 \%)$ showed concentrations up to this level. As surface waters can have arsenic concentrations ranging from $0.5 \mu \mathrm{g} \mathrm{L}{ }^{-1}$ to more than $5000 \mu \mathrm{g} \mathrm{L}^{-1}$, with the most common values below $10 \mu \mathrm{g} \mathrm{L}^{-1}$, and often less than $1 \mu \mathrm{g} \mathrm{L}^{-1}$ (Smedley and Kinniburgh, 2002), the high limit of quantification did not allow a more detailed statistical analysis of the water samples. However, the distribution of points with values above the limit of quantification show important trends, with waters rich in As occurring not only in the Carmo River (Borba et al. 2000; Deschamps et al. 2002; Borba et al. 2003; Varejão et al. 2011), Velhas River (Borba et al. 2000; Matschullat et al. 2000; Deschamps et al. 2002; Borba et al. 2003, Matschullat et al. 2007) and Conceição River basins (Borba et al. 2000; Matschullat et al. 2000; Deschamps et al. 2002; Borba et al. 2003, Matschullat et al. 2007), but also in the Paraopeba and Piracicaba River basins. (Figure 2b)

of 2.1 and $2.4 \mathrm{mg} \mathrm{kg}^{-1}$, respectively; higher than over the other lithologies in the area.

Areas of environmental preservation in the upper Velhas River basin show values from 2.4 to $5.7 \mathrm{mg} \mathrm{Cd} \mathrm{kg}{ }^{-1}$, demonstrating the natural release of trace elements from rocks and soils. It is worth mentioning that in stretches, where significant $\mathrm{Cd}$ anomalies were found, these were often associated with high $\mathrm{Pb}$ and $\mathrm{Zn}$-concentrations (Parra et al. 2007). The highest Cd-concentration lay at the Conceição River mouth with 12 significant anomalies (concentrations from 3.1 to $23 \mathrm{mg} \mathrm{Cd}$ $\mathrm{kg}^{-1}$ ). Here, a clear relationship with mining activities was observed.

Regarding surface water (Figure $3 \mathrm{~b}$ ), the IQ has Cd-values ranging from $<6.2$ to $202 \mu \mathrm{g}$. $\mathrm{L}^{-1}$. A number of 368 sampling points (68\%) contained values below the quantification limit of $6.2 \mu \mathrm{g} \mathrm{L}^{-1}$, which in this case was considered as the background value. On the other hand, 173 of the sample points showed concentrations above this level, which is higher than that recommended by Brazilian legislation $\left(5 \mu \mathrm{g}\right.$. $\left.\mathrm{L}^{-1}\right)$ for drinking water, showing that there is a great potential risk 

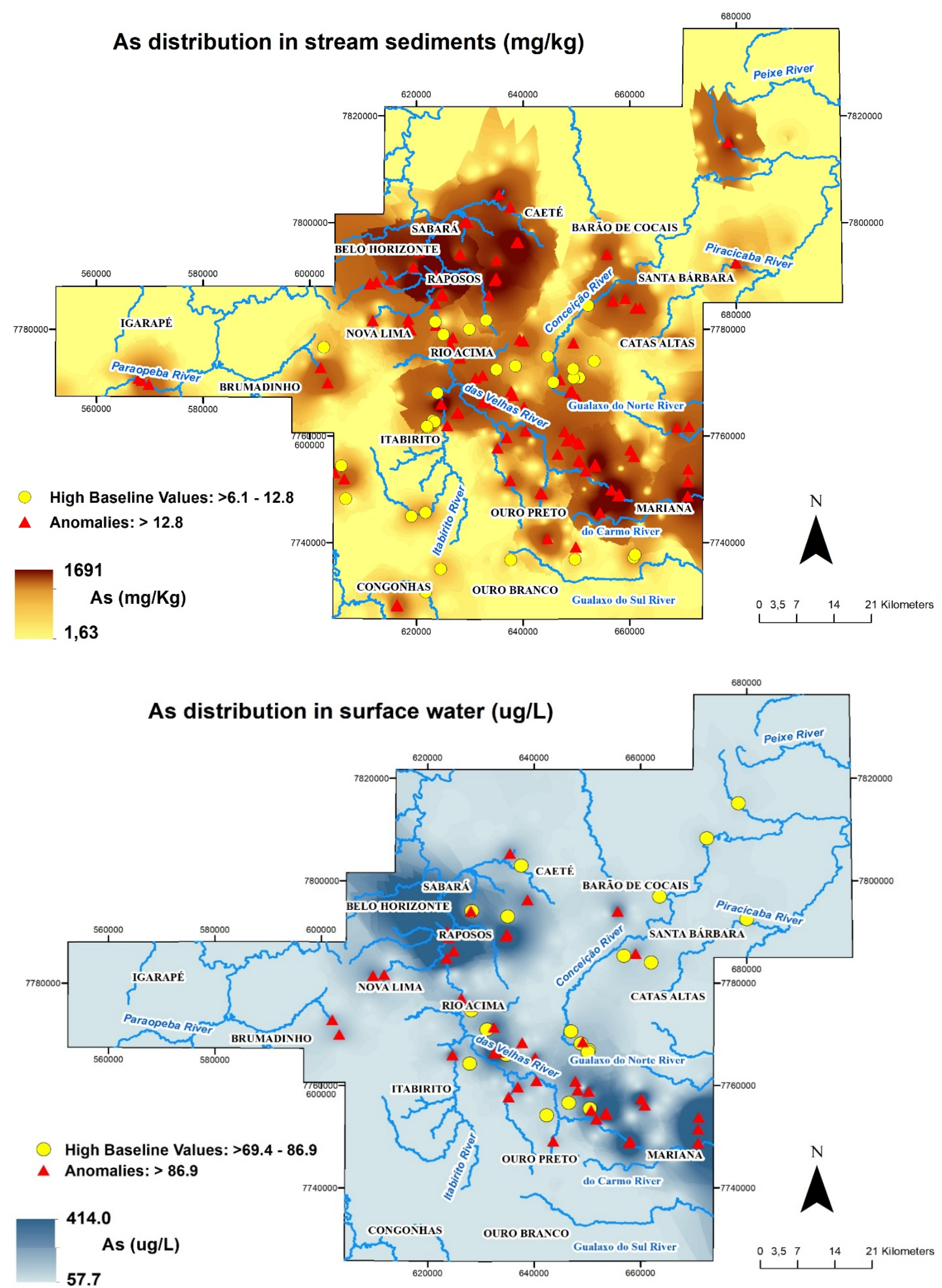

Figure 2

Arsenic distribution in stream sediments (a) and in surface waters (b) of the Iron Quadrangle. 

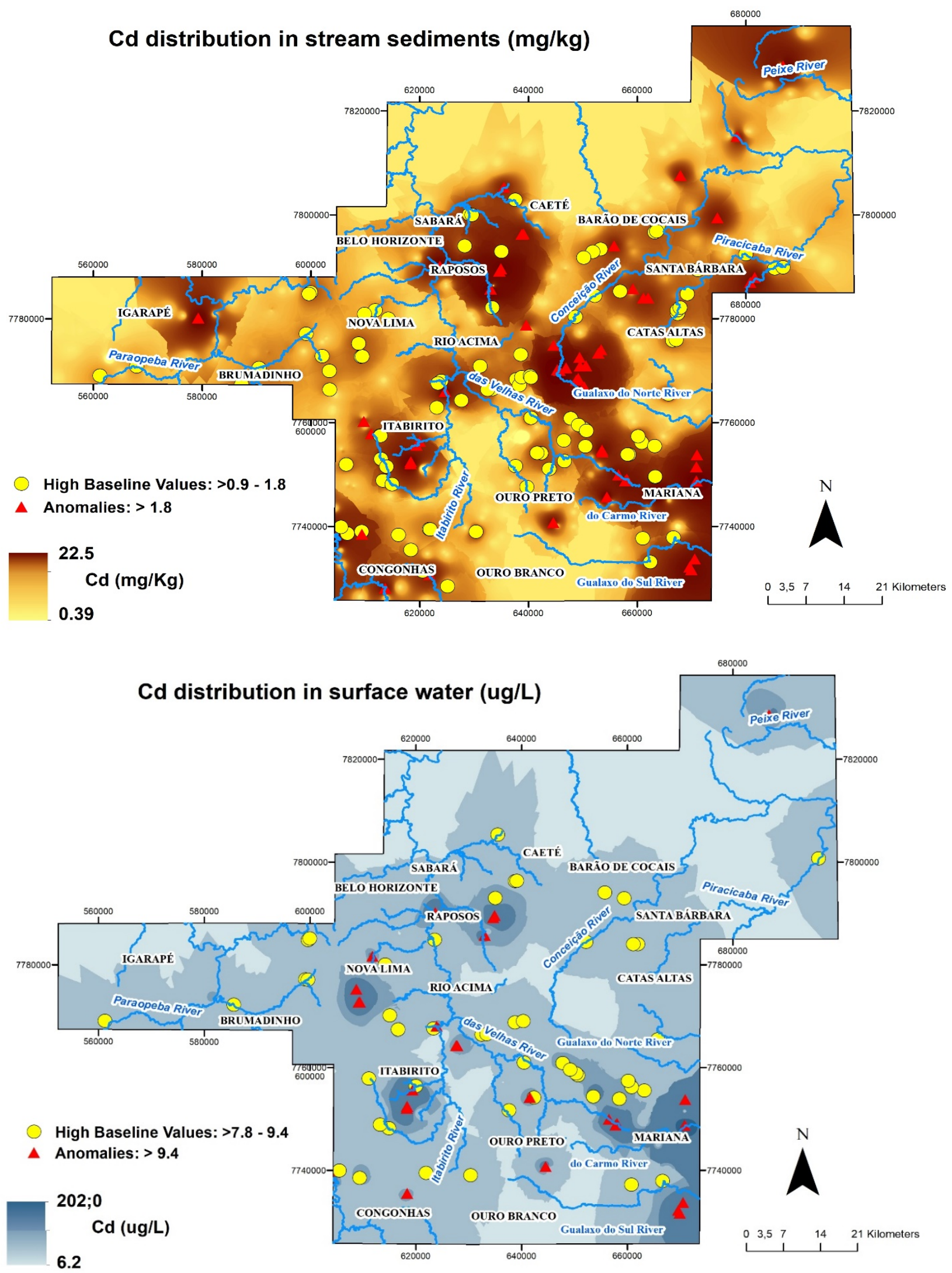

Figure 3

Cadmium distribution in stream sediments (a) and in surface waters (b) of the Iron Quadrangle. 
to the health of humans and animals in the region, because many rural communities in the region use these water resources for supply without any treatment.

Salminen et al (2005) report that median cadmium concentrations in surface waters around the world are $0.2 \mu \mathrm{g}$. $\mathrm{L}^{-1}$, and in the river waters are typically $<0.5 \mu \mathrm{g} . \mathrm{L}^{-1}$. Neal and Robson (2000) showed that about $4 \%$ of surface water had concentrations as high as $10 \mu \mathrm{g}$. $\mathrm{L}^{-1}$, basically equal to the high baseline limit of the IQ. However, $27 \%$ of the sample points in the IQ showed concentrations above this level, which were found mainly in Das Velhas and Rio do Carmo river basins.

In the Carmo river basin the higher values

\subsection{CHROMIUM AND NICKEL}

The Cr-distribution in stream sediments the IQ is very similar to that of $\mathrm{Ni}$ ( $73 \%$ of the sampling points show joint anomalies; (Figure 4a and 5a), reflecting the geology of the area. Seventy-three percent $(\mathrm{Cr})$ and $72 \%(\mathrm{Ni})$ of the sediments show concentrations below 128 and $43 \mathrm{mg} \mathrm{kg}^{-1}$ defined as background values respectively. Upper baseline values for $\mathrm{Ni}$ were reported in $22 \%$ of the samples with concentrations ranging from 43 to $96 \mathrm{mg} \mathrm{kg}$ 1 , and anomalous values were noted at 32 sites, showed Ni-concentrations above the UIF.

High baseline $\mathrm{Cr}$-concentrations between the background value and the UIF ranged from 128 to $269 \mathrm{mg} \mathrm{kg}^{-1}$ (Table 5). This comprises about 15\% of the samples, that along with the $\mathrm{Ni}$ anomalies, are located mainly in the centre of the IQ region, with anomalies related to the presence of Velhas River Supergroup rocks (Figures 1 and $4 a$ ). Indeed, 14 anomalies $\left(145-385 \mathrm{mg} \mathrm{kg}^{-1}\right)$ were observed in the upper Das Velhas river region, an area of low human interference (environmental preservation and two rural communities), draining rocks of the Nova Lima Group. In the same basin and on the same lithology in the municipalities of Rio Acima, Nova Lima, Caeté and Sabará (urbanization and intense mining activity), 27 anomalies were found $\left(140-570 \mathrm{mg} \mathrm{kg}{ }^{-1}\right)$. The highest density of stream sediments with high $\mathrm{Ni}$ concentrations (43-96 mg kg${ }^{-1}$ ) was detected in the central region along the Das Velhas river basin. That area contains the municipalities of Ouro Preto, Itabirito, Rio Acima and Nova Lima, and the river drains areas with schists of the Nova Lima Group (Figures 1 and 5a). Here, 41 streams with concentrations ranging from 44 to $157 \mathrm{mg}$ $\mathrm{kg}^{-1}$ were found. The abundant $\mathrm{Ni}$ and $\mathrm{Cr}-$ presence in sediments from these rocks originates from sulphidic and ultrabasic deposits.
(19.7 and $202 \mu \mathrm{g} . \mathrm{L}^{-1}$ ), were recorded in two locations along the Rio do Carmo itself, which flows through the cities of Ouro Preto, Mariana and other localities, being characterized by high anthropic influence through the discharge of domestic sewage and mining waste.

The Velhas River basin had 15 water samples with concentrations ranging from 11.8 to 19.6 $\mu \mathrm{g} . \mathrm{L}^{-1}$. (Figure 3b). Most of these anomalies were observed in areas of much mining-related interference and proximal to roads that give access to the mining companies. Anomalies were also found within urban areas, such as a point within the city of Nova Lima, which also contained values above the Brazilian drinking water guideline for $\mathrm{Ni}, \mathrm{As}, \mathrm{Pb}$.

The highest Ni-anomalies were located in the north-eastern IQ, in Catas Altas in the lower Serra do Caraça (518-623 mg kg${ }^{-1}$ ), and are co-located with the highest $\mathrm{Cr}$-concentrations $(2,460$ and $2,580 \mathrm{mg} \mathrm{kg}^{-1}$ ) of the entire IQ. These anomalies occur in basins, which drain undivided ultramafic and mafic rocks with high $\mathrm{Cr}$ and $\mathrm{Ni}$ concentrations (Costa 2007; Roeser et al. 2007; Figure 5). These high concentrations of chromium extended down the Conceição river basin with eight streams containing $108-680 \mathrm{mg} \mathrm{kg}^{-1}$, corroborating previous data from stream sediments obtained by Parra et al. (2007), to the municipality of Rio Piracicaba (126-230 $\mathrm{mg} \mathrm{kg}^{-1}$ ).

These sites drain schists, quartizites, ferruginous quartzite and meta-basalts of the Nova Lima Group (Figures 1 and 5a). Intense mining activities characterise the basin, which contributes to the availability of these elements to the environment. High concentrations of both elements were also observed in basins that drained granites and gneiss in the southwest portion of IQ, close from Congonhas, which could be an anomaly. However, diabase intrusions were found next to the collection sites, explaining the high concentrations in these areas (Carneiro et al. 1998).

One hundred and sixty sample locations showed sediment $\mathrm{Cr}$-concentrations above the CCME-intervention-limits for aquatic life. Most of these streams are tributaries of the Paraopeba and Piracicaba rivers.

Chromium values in IQ surface water ranged between $<5.3$ and $385.8 \mu \mathrm{g}$. $\mathrm{L}^{-1}$, with a median value of $8.5 \mu \mathrm{g}$. $\mathrm{L}^{-1}, 22$ times higher than the European median value (FOREGS, 2005) and 8.5 times higher the world median value (WHO, 2004). Salminen et al (2005) report concentrations 
of chromium in uncontaminated natural water are typically less than $10 \mu \mathrm{g} . \mathrm{L}^{-1}$ and the European Commission and US EPA threshold for drinking water is $50 \mu \mathrm{g} . \mathrm{L}^{-1} \mathrm{Cr}$. These levels allow us to conclude that the surface waters of the IQ have remarkably higher chromium values.

Seventy-three percent of the water samples contain $\mathrm{Cr}$ values of up to $55.2 \mu \mathrm{g} . \mathrm{L}^{-1}$ (Figure $4 \mathrm{~b}$ and Table 5), $18 \%$ of the samples contain an intermediate (upper baseline) concentration range with levels up to $102 \mu \mathrm{g} . \mathrm{L}^{-1}$, and 46 anomalies were found across all the river basins.

Chromium concentrations at 184 sample points (34\%) were above that allowed by Brazilian law for drinking water $\left(50 \mu \mathrm{g} . \mathrm{L}^{-1}\right)$, showing that there is a great potential risk to the health of humans, because many of these rivers supply water for a large population, which live in small cities, rural towns, rural communities and residential condominiums.

Anomalies were reported in the Paraopeba River basin (Figure 4b), where 12 locations had $\mathrm{Cr}$ values between 197.3 and $326.4 \mu \mathrm{g} . \mathrm{L}^{-1} \mathrm{Cr}$, some points were located within the city of Congonhas and suffer the discharge of domestic sewage. The Paraopeba and Piracicaba rivers are used for the water supply of many cities. Both rivers pass through many rural communities, where river water is directly abstracted for human consumption.

High concentrations were also observed in rivers located in the southwest portion of IQ, close from Congonhas, which drained on granites and gneiss, in areas of low environmental impact, but diabase intrusions were found next to the collection sites, explaining the anomalous concentrations in these areas.

Ten water samples with anomalous concentrations were found along the Das Velhas River basin (Figure 4b), with values ranging between 104 and $262.5 \mu \mathrm{g} . \mathrm{L}^{-1} \mathrm{Cr}$. These rivers were located in rural communities and in permanent preservation areas (PPA's) open to visitors. This demonstrates that weathering may release significant amounts of potentially hazardous elements from natural lithologies into the environment even in areas of low human interference.

Similarly, the highest stream water $\mathrm{Cr}$ anomalies were located in the northeastern IQ, in Catas Altas $\left(203-284 \mu \mathrm{g} . \mathrm{L}^{-1}\right)$, in areas which drain ultramafic and mafic rocks, and extended down the Santa Bárbara river basin including seven rivers with concentrations between (104$362 \mu \mathrm{g} . \mathrm{L}^{-1}$.)

The anomalous values continue to the municipality of Rio Piracicaba, but with higher levels reported there $\left(268.3-312.8 \mu \mathrm{g} . \mathrm{L}^{-1}\right)$. The predominant lithologies in these locations are schists, quartizites, ferruginous quartzite and meta-basalts of the Nova Lima Group, but the intense mining activity contributes to the availability of these elements to the environment.

The Ni distribution in IQ surface waters is similar to that of $\mathrm{Cr}$. Seventy-five percent of the samples contain $\mathrm{Ni}$ concentrations up to 38.4 $\mu \mathrm{g} . \mathrm{L}^{-1}$, (Figure $5 \mathrm{~b}$ and Table 5), which can be considered as the background value, $17 \%$ of the samples fall within the higher baseline concentration range up to $56.8 \mu \mathrm{g} . \mathrm{L}^{-1}$, and 69 anomalies were found across all the river basins.

The values of nickel ranged between $<20$ to $264.7 \mu \mathrm{g} . \mathrm{L}^{-1}$, with a median value of $23.4 \mu \mathrm{g} . \mathrm{L}^{-1}$, 9.4 times higher the world median value (WHO, 2004) and 12 times higher than the European value (FOREGS, 2005). Reimann and Caritat (1998) report that the average Ni concentrations in surface water vary from less than 1 to about 10 $\mu \mathrm{g} . \mathrm{L}^{-1}$, and just like $\mathrm{Cu}, \mathrm{Cr}, \mathrm{Cd}$ and $\mathrm{As}$, the waters of IQ have notably higher levels of nickel than world averages.

Fifty-two of the water samples (9.6\%) exceed the level allowed by Brazilian legislation for drinking water $\left(70 \mu \mathrm{g} . \mathrm{L}^{-1}\right)$, which shows again, that there is a population exposed to potential health risks, since the people who consume this water, which is treated by the municipal services, which only make simple chlorination.

Forty-two anomalous samples were found along the Das Velhas River basin (Figure 5b), the values ranged between 57.3 and $95.7 \mu \mathrm{g} . \mathrm{L}^{-1}$. The highest value found in this basin was located in a point within urban areas in the city of Nova Lima, which also contained values above the UIF for $\mathrm{Cd}, \mathrm{As}, \mathrm{Cu}$ and $\mathrm{Pb}$.

Anomalous concentrations were also reported in the Paraopeba River basin with eight rivers showed values between 78.3 and $241.5 \mu \mathrm{g} . \mathrm{L}^{-1} \mathrm{Ni}$. This basin shows a very strong spatial association between $\mathrm{Ni}$ and $\mathrm{Cr}$, with $75 \%$ of the sample points presenting joint anomalies.

Concentrations above the Ni UIF were also found in the Carmo river basin (127.3 and 153.7 $\left.\mu \mathrm{g} . \mathrm{L}^{-1}\right)$ at the same points where $\mathrm{Cd}, \mathrm{Pb}, \mathrm{Cu}$ and $\mathrm{Zn}$ anomalies were found. This river flows through the cities of Ouro Preto, Mariana and other localities, characterized by the discharge of domestic sewage and mining waste. Just like chromium, the highest $\mathrm{Ni}$ anomalies were located in the Santa Bárbara / Rio Piracicaba basin, again a strong spatial association between $\mathrm{Ni}$ and $\mathrm{Cr}$ was verified, with $85 \%$ of the sample locations presenting joint anomalies. 

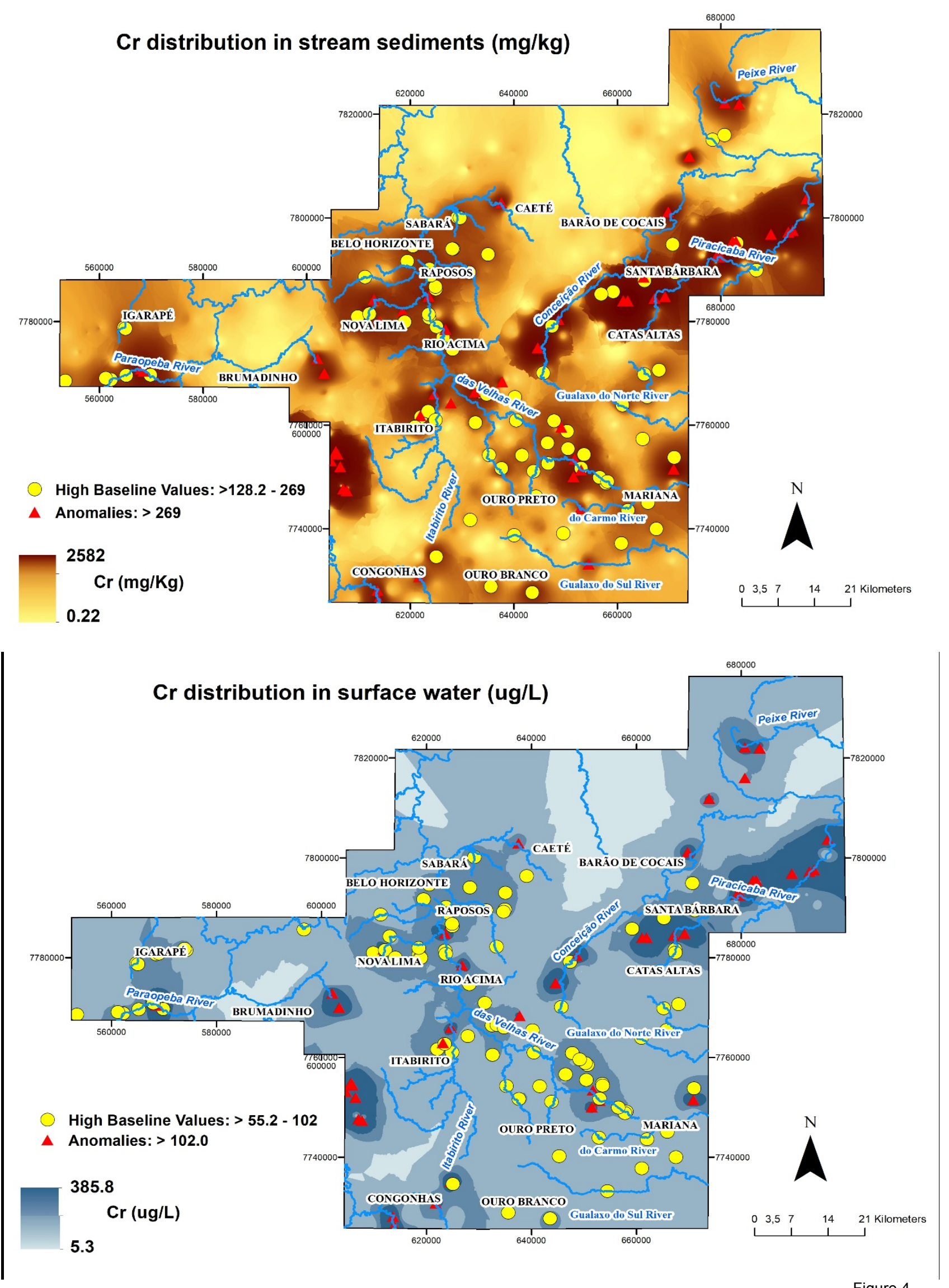

Chromium distribution in stream sediments (a) and in surface waters (b) of the Iron Quadrangle. 

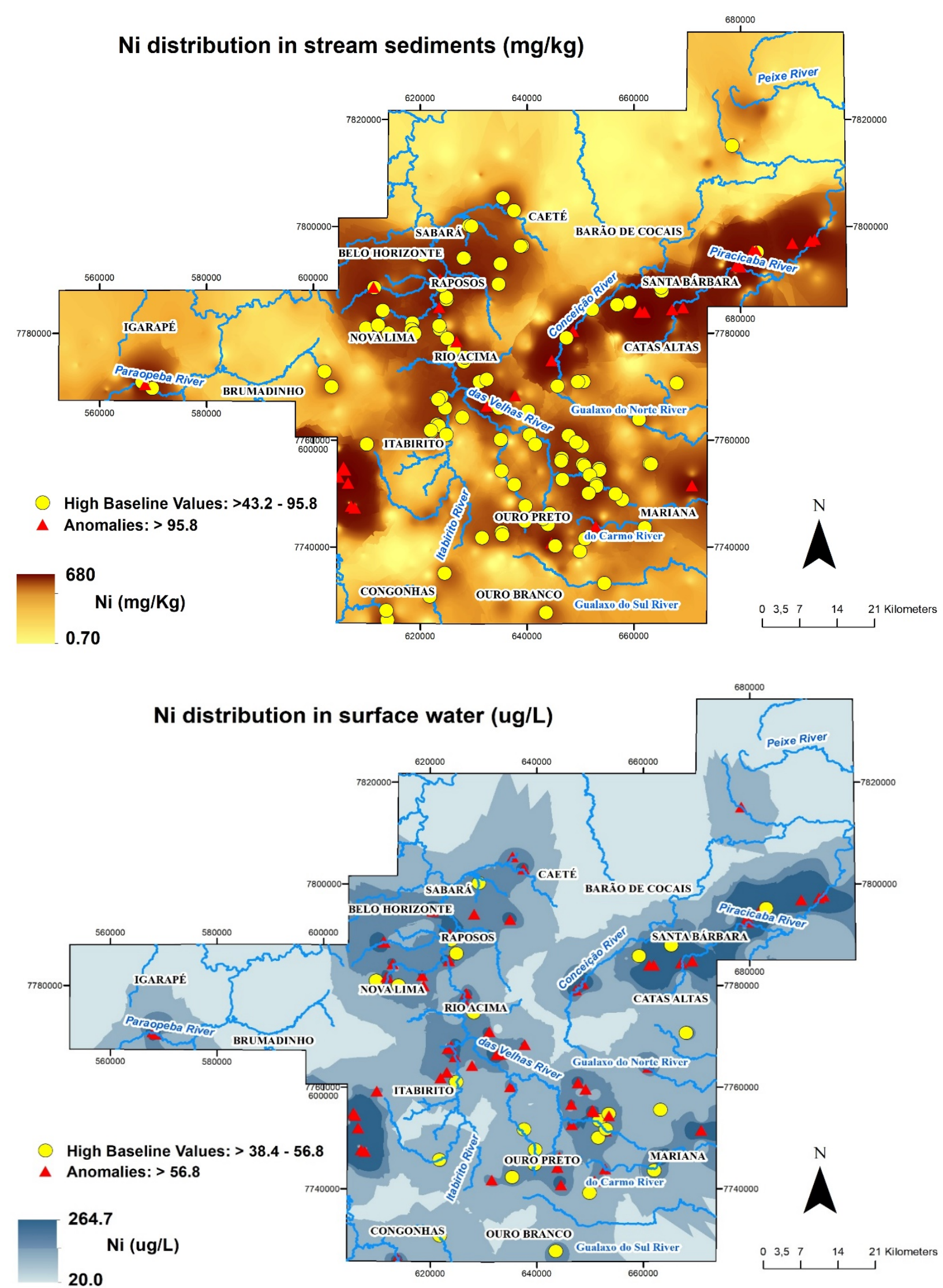

Figure 5 Nickel distribution in stream sediments (a) and in surface waters (b) of the Iron Quadrangle. 
Anomalous $\mathrm{Ni}$ values were found in Catas Altas (157-201.2 $\left.\mu \mathrm{g} . \mathrm{L}^{-1}\right)$, in rivers which drain on ultramafic and mafic rocks, and in the Santa Bárbara river basin with eight waters with values between $71.4-251.8 \mu \mathrm{g} . \mathrm{L}^{-1}$. Still in the same basin, but unlike chromium, because the values do

\subsection{COPPER}

The IQ sediments showed $\mathrm{Cu}$-concentrations of up to $33 \mathrm{mg} \mathrm{kg}^{-1}$ (Figure 6a), as the regional background. Eighteen high baseline values lie between 33-68 mg kg-1 (Table 5) and show a close relationship with schists of the Nova Lima Group reflecting the presence of chalcopyrite in this rock unit.

The largest anomalies were found along the Das Velhas river basin, with many rivers draining these rocks. In the upper part of the basin, nine sediments with anomalous concentrations were located in rural communities and in permanent preservation areas (PPA's) open to visitors. This demonstrates that weathering may release significant amounts of elements from these lithologies into the environment even in areas of low human interference. In the north-western region of the IQ, including municipalities of Igarapé and Brumadinho (Metropolitan Region of Belo Horizonte), anomalies were observed in rivers that drain schists of the Nova Lima Group (35-72 $\mathrm{mg} \mathrm{kg}^{-1}$ ). Most of these streams are located in areas with vegetable production, where $\mathrm{Cu}$-based fungicides are intensely applied, which may influence the sediments (Albanese et al. 2006).

Larger anomalies were observed in another part of the IQ, including the municipalities of Itabirito, Rio Acima, Nova Lima, Raposos and Caeté. Here, 32 rivers were sampled, of which 21 showed high sediment $\mathrm{Cu}$ concentrations (41-233 $\mathrm{mg} \mathrm{kg}{ }^{-1}$ ). These drainage systems are located in highly urbanized areas with intense mining and industrial activity.

The IQ surface waters showed $\mathrm{Cu}$ values which ranged from $<3.13-263.8 \mu \mathrm{g} . \mathrm{L}^{-1}$, with concentrations up to $60,4 \mu \mathrm{g} . \mathrm{L}^{-1}$ (Figure $6 \mathrm{~b}$ and Table 5), considered as the background value. The median value was $3.6 \mu \mathrm{g} . \mathrm{L}^{-1}$, four times higher

\subsection{LEAD}

The Pb-distribution in $78 \%$ of the IQ stream sediments was characterized by low concentrations (1.00-32 mg kg-1) (Figure 7a), taken to be the regional background (Table 5). The high baseline ranged from 32 to $59 \mathrm{mg} \mathrm{kg}^{-1}$, and is closely related to lithology mainly phyllites not rise, anomalous values were found in the city of Rio Piracicaba $\left(93.5\right.$ - $\left.189.4 \mu \mathrm{g} . \mathrm{L}^{-1}\right)$, the intense mining activity combined with lithology are factors that contribute to the availability of this element in the environment.

than the median European stream water value. FOREGS (2005) stated that levels around 10 $\mu \mathrm{g} . \mathrm{L}^{-1}$ are fairly typical in uncontaminated and natural water, it is concluded that the surface waters of IQ have notably higher copper values.

Allied to this, the same authors also report that concentrations of a few hundred $\mu \mathrm{g} . \mathrm{L}^{-1}$ may be related to the acid drainage of the mines, which was also found in IQ, at sampling points located near mining sites in the cities of Itabirito and Santa Bárbara, corroborating previous work by Mendonça (2012), which also reported very low $\mathrm{pH}$ values in this area. Stream water $\mathrm{Cu}$ concentrations above the high baseline value (117.2 $\left.\mu \mathrm{g} . \mathrm{L}^{-1}\right) \quad$ were found at 34 places, distributed in all river basins.

The largest anomalies were found along the Das Velhas River basin (Figure 6b), where 16 rivers with values ranging between 117.3 and 263.8 $\mu \mathrm{g} . \mathrm{L}^{-1}$ were recorded. In the middle section of the basin, twelve locations with anomalous concentrations were observed, most of them located within the cities (Nova Lima, Rio Acima and Honório Bicalho) showing a close relationship with schists of the Nova Lima Group and the intense occupation and use of the land.

Anomalous concentrations were also observed in the southeastern region of the IQ, in the Carmo river basin with values ranging between 105.3 and $173.5 \mu \mathrm{g} . \mathrm{L}^{-1}$ at the same locations where cadmium and nickel anomalies were found, characterized by the discharge of domestic sewage and mining waste.

Anomalies were reported in the surface waters of the Paraopeba River basin with values between 153.8 and $184.7 \mu \mathrm{g} . \mathrm{L}^{-1}$ located in the upper part of the basin, in the city of Congonhas, at sampling points downstream of a steel plant.

and itabirites of the Minas Supergroup. Anomalies above $59 \mathrm{mg} \mathrm{kg}^{-1}$ showed a significant spatial colocation with $\mathrm{Fe}$, seventy-two percent of the sites displayed $\mathrm{Fe}$-anomalies jointly with high $\mathrm{Pb}$ concentrations. 

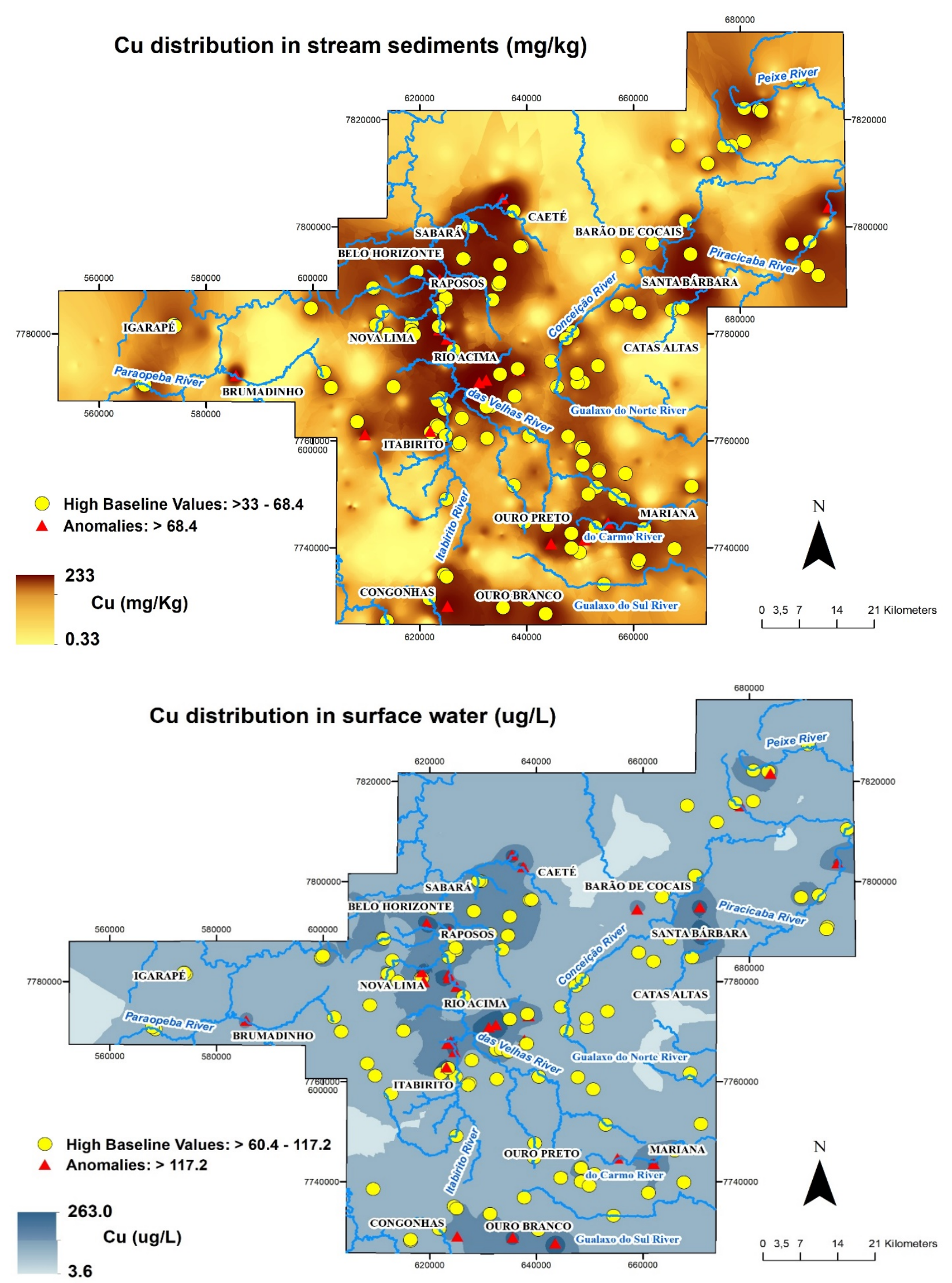

Figure 6 Cooper distribution in stream sediments (a) and in surface waters (a) of the Iron Quadrangle. 
The highest $\mathrm{Pb}$-concentrations were found in areas heavily impacted by mining activities, and related to phyllites and itabirites of the Minas Supergroup (Figures 1 and 7a). These anomalies are located in the central western region of the IQ, especially in the Paraopeba River and the Das Velhas River basins; an area with ten active mining companies. In this region, 21 streams showed elevated concentrations of $\mathrm{Pb}$ in sediment (38-70 $\mathrm{mg} \mathrm{kg}^{-1}$ ).

Lead also served well as a geochemical marker because at sampling points close to regions that contain rocks with high levels and mining activities, there are high concentrations of this element in the sediments, and from the distance of these points there is a decrease in the concentration of lead e.g., in the Congonhas region (southwest portion of IQ), where the predominant rock types are granites and gneisses. Lead concentrations ranged from 40 to $50 \mathrm{mg} \mathrm{kg}^{-}$ ${ }^{1}$, which may be explained by the iron ore mining activities upstream of this area. A hypothesis supported by those collection locations that showed advanced siltation. The Pb-content decreased significantly with increasing distance from the mining companies, located at the top of the syncline (Figures 1 and $7 \mathrm{a}$ ).

The lead values in surface water ranged from $<$ 7.2 to $214.7 \mu \mathrm{g} . \mathrm{L}^{-1}$, with a median value of 8.3 $\mu \mathrm{g} . \mathrm{L}^{-1}$, these values are significantly higher than those observed in Europe, which ranged from < 0.005 to $6.37 \mu \mathrm{g} . \mathrm{L}^{-1}$, (median: $0.093 \mu \mathrm{g} . \mathrm{L}^{-1}$ ) (Salminen et al, 2005).

Seventy-six percent of samples had $\mathrm{Pb}$ values of up to $29.4 \mu \mathrm{g} . \mathrm{L}^{-1}$ which can be considered as the regional background (Figure $7 \mathrm{~b}$ and Table 5).

\subsection{ZINC}

Sediment $\mathrm{Zn}$ concentrations range between 1.6 and $340 \mathrm{mg} \mathrm{kg}^{-1}$, with a median of $47 \mathrm{mg} \mathrm{kg}^{-1}$, (Figure 8a). Twenty-seven samples show values above the UIF ( $>98 \mathrm{mg} \mathrm{kg}^{-1}$; Table 5).

The highest Zn-concentrations showed no relationship with a specific lithotype, since excessive concentrations were found both in schists of the Rio das Velhas River Supergroup and itabirites of the Minas Supergroup (Figure 1 and Figure 8a). This unspecific Zn-behaviour in sediments can be partially explained by its ability to replace $\mathrm{Fe}$ and $\mathrm{Mn}$ in oxides and silicates, which significantly increases its presence in clay minerals, iron oxides and organic substances (Reimann and Caritat 1998), allowing it to be found even in regions far away from source areas (Figures 1 and 8a).
Ninety samples with $\mathrm{Pb}$ concentrations above the high baseline value $\left(51.6 \mu \mathrm{g} . \mathrm{L}^{-1}\right)$ were found across all river basins

In the Paraopeba river basin two important trends were recognized: (a) in areas of low environmental impact, but in basins draining on phyllites and itabirites of the Minas Super Group values between 52 to $63 \mu \mathrm{g} . \mathrm{L}^{-1} \mathrm{~Pb}$ in stream water were found and (b) in rivers draining the same lithologies but with sites heavily impacted by mining activities, higher values between 58.7 and 183.4 $\mu \mathrm{g} . \mathrm{L}^{-1} \mathrm{~Pb}$ were recorded. In the Velhas River basin, twenty-four stream waters showed concentrations from 52.5 to $201.4 \mu \mathrm{g} . \mathrm{L}^{-1}$, most of these are located in rural communities, which have a great quantity of domestic sewage released in the rivers, although some of the high values were within cities (Nova Lima and Itabirito).

Almost 28\% (149) of the stream waters, showed values of lead above that allowed by Brazilian legislation for drinking water $\left(10 \mu \mathrm{g} . \mathrm{L}^{-}\right.$ ${ }^{1}$ ). Since many of these rivers are used as a source of water supply for urban agglomerations, rural communities, and farms, there is potential for a large population to be exposed to higher than recommended lead intake, mainly in the cities of Ouro Preto, Nova Lima, Itabirito, Congonhas, Mariana and Barão de Cocais, although water is treated before being distributed to the population, in many cities in the IQ region, the water treatment is not planned to remove hazardous elements from water, moreover, in many rural communities the water treatment is done only with a simple chlorination, so it is important to show these numbers.

Zinc shows anomalies similar to $\mathrm{As}, \mathrm{Cu}, \mathrm{Ni}$ and $\mathrm{Cr}$ in the northern portion of the Das Velhas River basin; in the municipalities of Caeté, Rio Acima and Nova Lima, a region greatly affected by mining and urbanization. Here, 21 anomalies were found, with concentrations from 66 to 320 $\mathrm{mg} \mathrm{kg}{ }^{-1}$, all of them on streams draining metabasalts and schists of the Nova Lima Group. Seven sites with higher sediment $\mathrm{Zn}$ concentrations $\left(63-120 \mathrm{mg} \mathrm{kg}^{-1}\right)$ were found in the municipality of Itabirito in the same basin, which is underlain by itabirites, hematite and phyllites of the Minas Group.

These sites are located in areas heavily impacted by mining activities and show concurrent $\mathrm{Fe}$ and $\mathrm{Pb}$-anomalies in the sediments. Anomalous concentrations were also detected at 


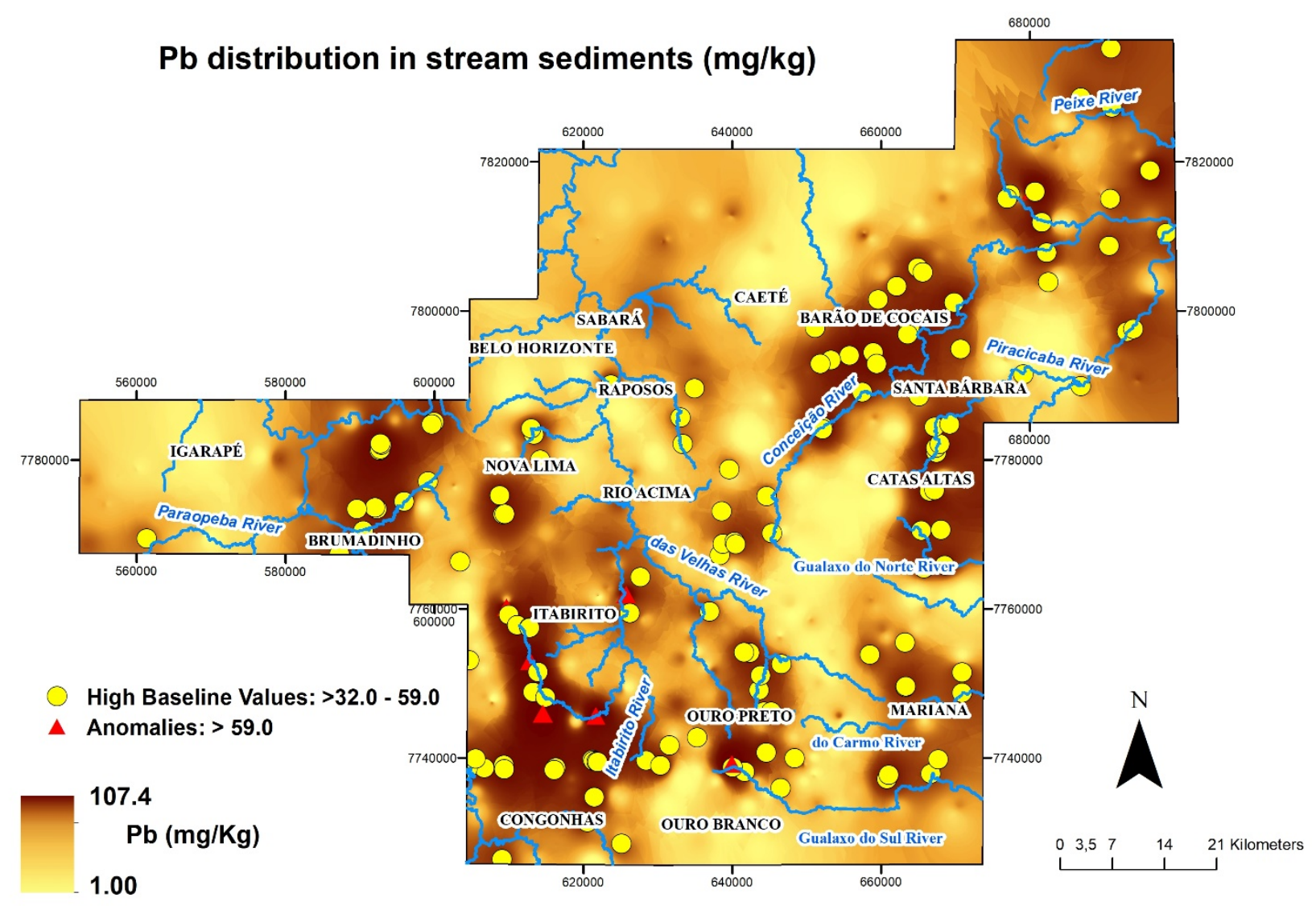

$\mathrm{Pb}$ distribution in surface water (ug/L)

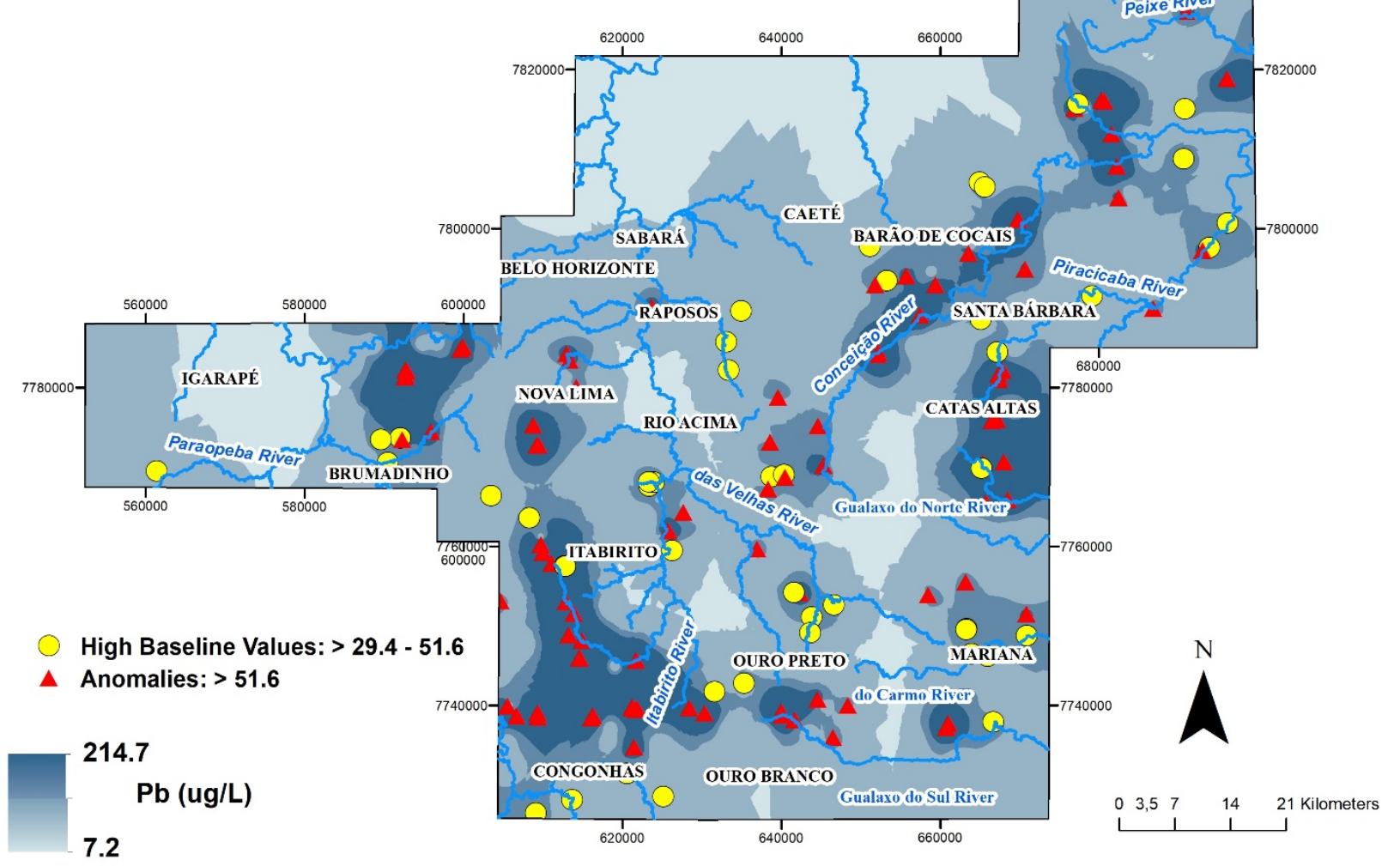

Figure 7 Lead distribution in stream sediments (a) and in surface waters (b) of the Iron Quadrangle. 
another seven sites in the Upper Doce River basin, which lie on quartzites of the Itacolomi Group, phyllites of the Minas Group and schists of the Nova Lima Group.

The lithological composition allows for a limited release of $\mathrm{Zn}$ only (up to $60 \mathrm{mg} \mathrm{kg}{ }^{-1}$ ), considered the regional background (Table 5). Values in the range from 60 to $98 \mathrm{mg} \mathrm{kg}^{-1}$ (high baseline) can be attributed to the combination of lithology and possible anthropogenic interference.

Indeed, in the majority of the sediments $\mathrm{Zn}$ values are below the limits of intervention recommended by the CCME (2000), only 56 sediments had concentrations above this limit, of which 31 were found in the Velhas river basin in urbanized and industrialized regions impacted by mining activities. The highest $\mathrm{Zn}$-concentration in the entire IQ (340 $\left.\mathrm{mg} \mathrm{kg}^{-1}\right)$ was located downstream of a steel industry in the city of Congonhas. This stream also showed $\mathrm{Ca}, \mathrm{Cu}, \mathrm{Mn}$, $\mathrm{Mo}, \mathrm{K}, \mathrm{Na}$, and $\mathrm{Cr}$-anomalies as well as a very high alkaline $\mathrm{pH}$ (9.4).

Interestingly, among the sediment anomalies located in the upper part of the Doce River basin, three are located downstream of a metallurgical company (110 to $131 \mathrm{mg} \mathrm{kg}^{-1} \mathrm{Zn}$ ), which also showed elevated $\mathrm{Mn}, \mathrm{Ni}, \mathrm{Co}$ and $\mathrm{Cu}-$ concentrations. In the Piracicaba River basin, anomalies were found in the cities of Barão de Cocais and Santa Bárbara (64-179 $\mathrm{mg} \mathrm{kg}^{-1}$ ); again likely related to human interference, as they were mostly found in urban streams or near industrial or mining activities.

The $\mathrm{Zn}$ values in surface water ranged from $<$ 3.6 to $2198 \mu \mathrm{g}$. $\mathrm{L}^{-1}$, with a median value of 46.8 $\mu \mathrm{g}$. $\mathrm{L}^{-1}, 2.3$ times higher than the world median value (WHO, 2004) and 20 times higher the European value (FOREGS, 2005).

These numbers allow the conclusion that the surface waters of IQ have notably higher $\mathrm{Zn}$ values. Confirming this, WHO (2004) reports that in natural surface waters, the concentration of $\mathrm{Zn}$ is usually below $10 \mu \mathrm{g}$. $\mathrm{L}^{-1}$.

Sixty-eight percent of the water samples had $\mathrm{Zn}$ concentrations up to $83.6 \mu \mathrm{g} . \mathrm{L}^{-1}$ which can be considered as the background value. Zinc concentrations above the UIF value $\left(144.2 \mu \mathrm{g} . \mathrm{L}^{-1}\right)$ were found at 61 sample locations across all the river basins.
Zinc shows anomalies in the Velhas river basin with 13 stream waters showing values between 144.8 and $219 \mu \mathrm{g} \cdot \mathrm{L}^{-1}$, in areas with high population density, characterized by intense use and occupation of the soil, mainly in the municipalities of Nova Lima, Sabará and Caeté.

Anomalous concentrations were detected also at Piracicaba river basin, with values ranging from 153 to $436.2 \mu \mathrm{g} . \mathrm{L}^{-1}$. These streams were located within cities or near industrial or mining activities in Rio Piracicaba, Barão de Cocais and Santa Bárbara.

However, the largest density of anomalies is in the southern portion of the IQ, in the Upper Doce River basin (Gualaxo do Sul and do Carmo river sub-basin), where 25 stream waters with values between 540 and $2198 \mu \mathrm{g} . \mathrm{L}^{-1}$ are located in the municipalities of Ouro Branco and Ouro Preto . These anomalies can be attributed to the combination of lithology and possible anthropogenic interference because most of them were detected in areas that drain on phyllites and itabirites of the Minas Super Group, but the highest values were observed in rivers near a metallurgical company, which also showed elevated $\mathrm{Mn}, \mathrm{Ni}$, and $\mathrm{Cu}$ concentrations.

In summary, seventy-two to $78 \%$ of the IQ stream sediment samples showed no positive As, $\mathrm{Cd}, \mathrm{Cr}, \mathrm{Ni}, \mathrm{Cu}, \mathrm{Pb}$ and $\mathrm{Zn}$-anomalies (Table 5) which clear shows signatures of the lithological background. Fifteen to $24 \%$ revealed positive anomalies (high baseline) for these elements that could be related to geogenic factors, and $2-12 \%$ of the area represented unusually high concentrations (anomalies) that may be related to both mineralization and to human interference, notably mining activities.

With regard to surface water, similar percentages were found, with sixty-eight to $76 \%$ of the IQ samples presenting values up to Q3 (background) for $\mathrm{As}, \mathrm{Cd}, \mathrm{Cr}, \mathrm{Ni}, \mathrm{Cu}, \mathrm{Pb}$ and $\mathrm{Zn}$. Fourteen to $22 \%$ of the samples contained values between Q3 (background) and UIF (high baseline), which represent anomalies related to geology, and $5-10 \%$ of the samples show uncommonly high values, that may be related to both mineralization and to anthropogenic action, mainly discharge of domestic sewage and mining waste. 


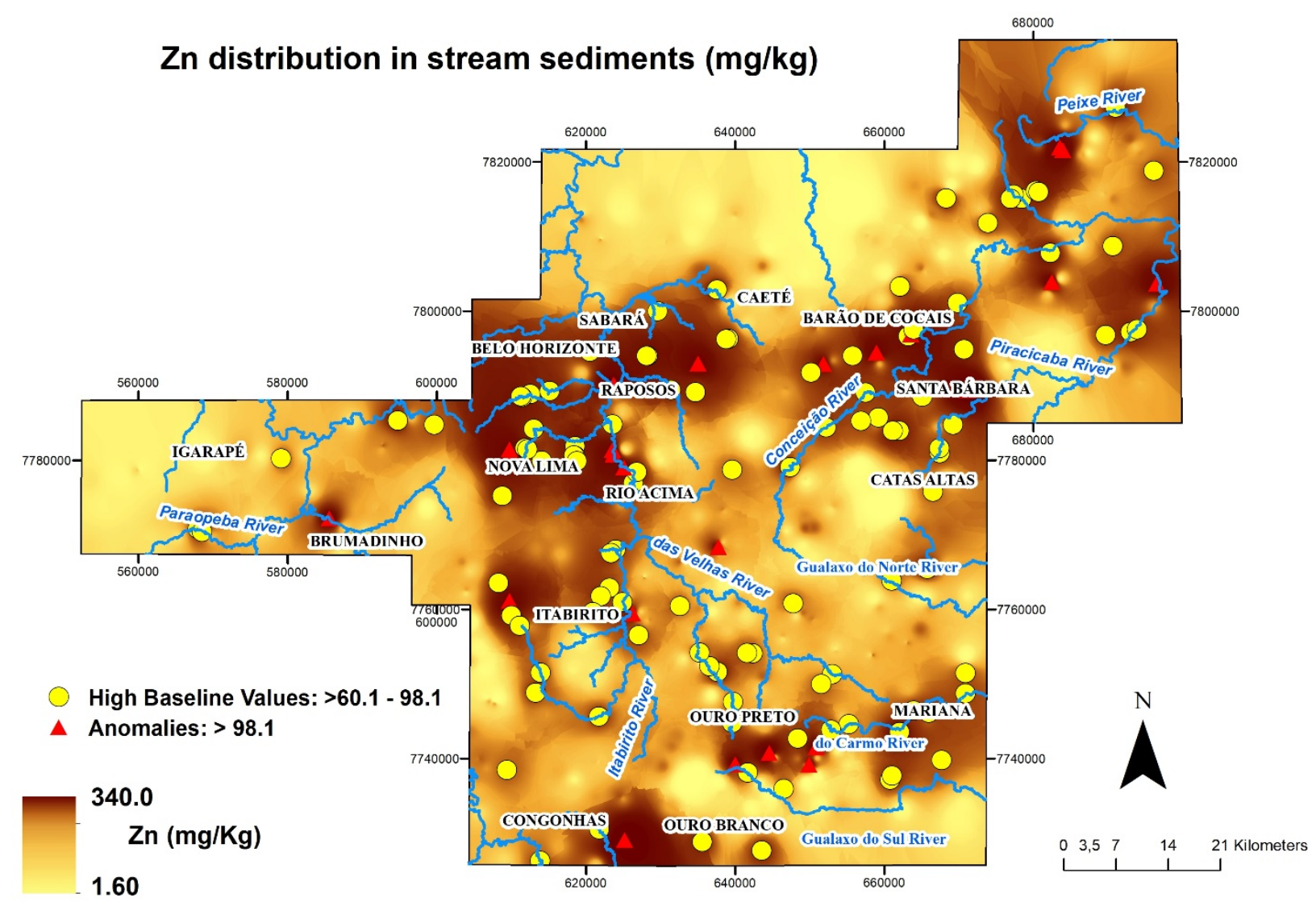

\section{Zn distribution in surface water (ug/L)}

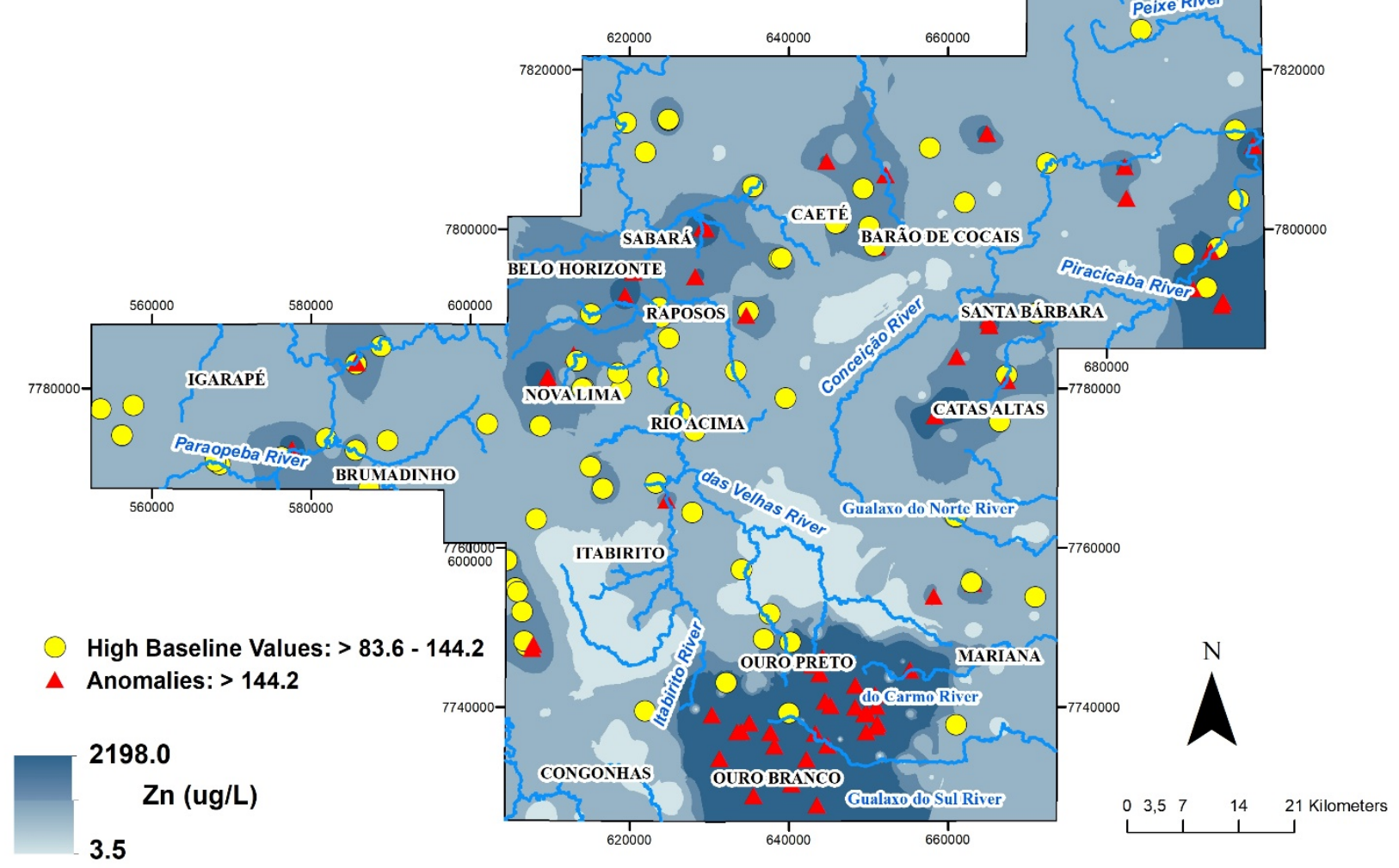

Figure 8

Zinc distribution in stream sediments (a) and in surface waters (b) of the Iron Quadrangle. 


\section{CONCLUSIONS}

For the first time, regional background values can be presented for selected chemical elements of IQ stream sediments. These background values are near or even below the upper crustal averages. This study allowed the establishment of baseline values for the most significant IQ drainage basins. The wide variety of locations and rock types is reflected in a large variability of element concentrations - up to three orders of magnitude, which was not observed in previous studies from the region (Matschullat et al. 2000b; APA Sul 2005; Costa 2007; Mendes 2007; Mendonça 2012; Parra et al. 2007; Pereira et al. 2007) - due to their more localized focus. Most noticeable are the depleted plant nutrients $(\mathrm{Ca}, \mathrm{Mg}$ and $\mathrm{K})$, with consequences for agriculture, depletion of these elements in stream sediment is indicative of the surrounding bedrock and tropical weathering and likely to affect soils also.. This work also reveals anomalies of selected elements for river basins, where so far no anomalous sediment concentrations had been reported. Chromium, Ni and Co-concentrations in the upper part of the Piracicaba River basin and As-anomalies in the Paraopeba River basin may serve as examples.

Anomalous concentrations of several elements in stream sediments were found across the IQ. Many streams show $\mathrm{As}, \mathrm{Cd}, \mathrm{Cr}, \mathrm{Cu}, \mathrm{Ni}, \mathrm{Pb}$ and Zn-concentrations above Canadian sediment recommended PEL-values to protect aquatic life. These sediments often demonstrate a distinct anthropogenic interference, located downstream of mines. These need to be monitored, as any changes in $\mathrm{pH}$ and Eh (redox potential), which may occur due to the discharge of sewage or effluents, could change the environmental conditions and promote the mobility and biological availability of potentially hazardous elements into the water column; thus the entire food chain (Costa 2007; Matschullat 2000a et al. ; Pereira et al. 2007).

Regarding surface waters, many locations were also observed where metal concentrations were above the Brazilian Drinking Water Guidelines, mainly for $\mathrm{As}, \mathrm{Cd}, \mathrm{Cr}$ and $\mathrm{Ni}$. These may represent an environmental exposure risk for a significant portion of the population where these waters are used directly for drinking.

In areas with high population density, with domestic sewage discharge and intense use and occupation of the land or in sites close to industrial or mining activities, the high concentrations of metals were reported in stream waters, demonstrating that these areas should be monitored with more attention by the environmental agencies.

The central part of the Das Velhas River basin, around the cities of Rio Acima, Nova Lima, Caeté, Sabará and Raposos, showed the highest density of $\mathrm{As}, \mathrm{Cd}, \mathrm{Cu}, \mathrm{Ni}, \mathrm{Cr}$ and $\mathrm{Zn}$-anomalies, both for surface waters and for stream sediments. Here, the elevated element concentrations occurred due to the interaction between geology and human interference. Many of these locations had high concentrations of potentially hazardous elements due to anthropogenic influence, and are therefore should be monitored.

However, many localities showed anomalous concentrations due to natural weathering processes, leading to a hidden environmental risk, and most of these areas are not currently monitored, but they should be. The newly generated geochemical maps will support a better environmental control. Authorities may particularly appreciate this new approach, since non-contaminated sediment and surface waters stretches dominate the region, and state controls can focus on specific problem areas - some of which are still unknown.

The chemical results obtained from the surface waters and sediments of this economically very important region for Brazil, and with its highly diverse geological characteristics, may serve as a guideline to define thresholds of action and intervention for environmental authorities. The new high-density mapping also allows delineation of those localities, cities and basins that represent higher environmental risks and thus need to be protected.

\section{ACKNOWLEDGMENTS.}

The authors highly appreciate the financial support of the institutions CNPq, FAPEMIG and mainly CAPES for the scholarship Proc. $\mathrm{n}^{\mathrm{o}}$ 10228/13-6. 


\section{REFERENCES}

Albanese S, De Vivo B, Lima A, Cicchella D (2006) Geochemical background and baseline values of toxic elements in stream sediments of Campania region (Italy). J Geochem Explor 93: 21-34

Alkmim FF, Marshak S (1998) Transamazonian orogeny in the southern São Francisco craton region, Minas Gerais, Brazil: Evidence for Paleoproterozoic collision and collapse in the Quadrilátero Ferrífero. Precambrian Res 90: 29-58

Almeida L A T D M (2005) Atlas Geoquímico dos solos das Bacias Hidrográficas dos rios Douro e Mondego. Master thesis, Universidade de Aveiro. Departamento de Geociências

APA Sul RMBH (2005) Projeto de geoquímica ambiental, mapas geoquímicos escala 1:225.000. Fernanda G. da Cunha, Gilberto J. Machado - Belo Horizonte: SEMAD/CPRM, 2005. 80p., v.7:17 mapas (Série Programa Informações Básicas para a Gestão Territorial - GATE)

Bai J, Porwal A, Hart C, Ford A, Yu L (2009) Mapping geochemical singularity using multifractal analysis: Application to anomaly definition on stream sediments data from Funin Sheet, Yunnan, China. J Geochem Explor 104: 1-11

Babinski, M.; Chemale, F.; Van Schumus, W.R. 1995. $\mathrm{The} \mathrm{Pb} / \mathrm{Pb}$ age of the Minas Supergroup carbonate rocks, Quadrilátero Ferrífero, Brazil. Precambrian Research, 72:235-245.

Baltazar, O.F., Zucchetti, M., 2007. Lithofacies associations and structural evolution of the Archean Rio das Velhas greenstone belt, Quadrilátero Ferrifero, Brazil: A review of the setting of gold deposits. Ore Geol. Rev. 32, 471-499. doi:10.1016/j.oregeorev.2005.03.021

Bølviken B, Bogen J, Jartun M, Langedal M, Ottesen RT, Volden T (2004) Overbank sediments: a natural bed blending sampling medium for largescale geochemical mapping. Chemometr Intell Lab 74: 183-199.Borba R. P., Figueiredo B. R., Rawlins B., Matschullat J. 2000. Arsenic in Water and Sediment in the Iron Quadrangle, State of Minas Gerais, Brazil. Applied Geochemistry, 15 (2): 181190.

Borba, R. P., Figueiredo, B. R., Matschullat, J. (2003). Geochemical distribution of arsenic in waters, sediments and weathered gold mineralized rocks from Quadrilátero Ferrífero, Brazil. Environmental Geology, v. 44, n. 1, p. 39-52.

Brazil. Ministry of health. Decree 2914, december, 12, 2011. Brasília, DF, 2011.Caritat P, Lech M, Mcpherson A, Phillips D (2007) National Geochemical Survey of Australia: outline of a new proposal. Geoscience Australia. 48 p.

Cabral AR, Zeh A, Koglin N, Seabra Gomes Jr AA, Viana DJ, Lehmann B (2012) Dating the Itabira iron formation, Quadrilátero Ferrífero of Minas Gerais, Brazil, at 2.65 Ga: Depositional $\mathrm{U}-\mathrm{Pb}$ age of zircon from a metavolcanic layer. Precambrian Research 204-205:40-45.

Caritat, P. de, Cooper, M. (2011) National Geochemical Survey of Australia: The
Geochemical Atlas of Australia. Geoscience Australia, Record 2011/20 (2 Volumes), 557 p.

Carneiro MA, Carvalho Júnior IM, Teixeira W (1998) Petrologia, geoquímica e geocronologia dos diques máficos do complexo metamórfico Bonfim Setentrional (Quadrilátero Ferrífero) e suas implicações na evolução crustal do cráton do São Francisco Meridional. Rev Brasil Geociências 28, 1: $29-44$.

Carneiro M.A. 1992. O Complexo Metamórfico Bonfim Setentrional (Quadrilátero Ferrífero, Minas Gerais): Litoestratigrafia e Evolução Geológica de um Segmento de Crosta Continental do Arqueano. Tese de Doutoramento, Instituto de Geociências, Universidade de São Paulo, 233p.

Carranza EJM (2009) Geochemical anomaly and mineral prospectivity mapping in GIS. Handbook of exploration and environmental geochemistry 11 : 310 p. Elsevier, Budapest, Hungary

CCME - Canadian Council of Ministers of the Environment (2000). Protocol for the derivation of Canadian sediment quality guidelines for the protection of aquatic life. Environment Canada, Guidelines Division Technical Secretariat of the CCME Task Group on Water Quality Guidelines, EPC-98E

Cheng Z, Xie X, Yao W, Feng J, Zhang Q, Fang J (2014) Multi-element geochemical mapping in Southern China. Journal of Geochemical Exploration 139: 183-192

Costa AT (2007) Registro histórico de contaminação por metais pesados, associadas à exploração aurífera no alto e médio curso da bacia do Ribeirão do Carmo, QF: um estudo de sedimentos de planícies de inundação e terraços aluviais. Doctoral thesis, UFOP, Ouro Preto

De Vivo B, Lima A, Boni M, Albanese S, Cicchella D, Iachetta A, Malanga F, Somma R, Tarzia M, Frizzo P, Raccagni L, Sabatini G, Baroni F, Di Lella LA, Protano G, Riccobono F (2003) FOREGS geochemical baseline mapping programme: Italian territory. $4^{\text {th }}$ European Congress on Regional Geoscientific Cartography and Information Systems. June 17-20, Bologna. Proceedings II: 639-640. Poster session

Deschamps E., Carneiro M. E. D. P., Ciminelli V. S. T., Peter W., Ramos A. 2002. Arsenic sorption onto soils enriched in Mn and Fe minerals. Clays and Clay Minerals, v. 51, p. 198-205.

Deschamps E, Matschullat J (eds, 2011) Arsenic: natural and anthropogenic. Arsenic in the Environment 4: 209 pp. CRC Press, Boca Raton.

Farina, F., Albert, C., Martínez Dopico, C., Aguilar Gil, C., Moreira, H., Hippertt, J.P., Cutts, K., Alkmim, F.F., Lana, C., 2016. The ArcheanPaleoproterozoic evolution of the Quadrilátero Ferrífero (Brasil): Current models and open questions. J. South Am. Earth Sci. 68, 4-21. doi:10.1016/j.jsames.2015.10.015.

Ferreira A, Inácio MM, Morgado P, Batista $\mathrm{MJ}$, Ferreira L, Pereira V, Pinto MS (2001) Low-density 
geochemical mapping in Portugal. Appl Geochem 16: $1323-1331$

FOREGS, (2005) EuroGeoSurveys : Geochemical Baseline Database, Geochemical Atlas of Europe, Part 1 and 2, including all original analytical and field data are freely available at http://weppi.gtk.fi/publ/foregsatlas/ last access: 03.06.2018.

IBGE - Instituto Brasileiro de Geografia e Estatística (2010) Censo Nacional. http:/www.censo2010.ibge.gov.br/ last access: 04.04.2015.

Ivanov V. V. (1996) Ecological geochemistry of elements. Ecology 1-6, Moscow, Russa.

Khalil A, Hanich L, Bannari A, Zouhri L, Pourret O, Hakkou R (2013) Assessment of soil contamination around an abandoned mine in a semi-arid environment using geochemistry and geostatistics: Pre-work of geochemical process modeling with numerical models. J Geochem Explor 125: 117-129

Krríbek B, Davies T C, De Vivo B (2014) Mining vs. environment in Africa. Journal of Geochemical Exploration 144: 387-580

Lapworth DJ, Knights KV, Key RM, Johnson CC, Ayoade E, Adekanmi MA, Arisekola TM, Okunlola OA, Backman B, Eklund M, Everett PA, Lister RT, Ridgway J, Watts MJ, Kemp SJ, Pitfield PEJ (2012) Geochemical mapping using stream sediments in west-central Nigeria: Implications for environmental studies and mineral exploration in West Africa. Applied Geochemistry 27:1035-1052

Li M, Xi X, Xiao G, Cheng H, Yang Z, Zhou G, Ye J, Li Z (2014) National multi-purpose regional geochemical survey in China. J Geochem Explor 139: $21-30$

Machado N, Schrank A, Noce CM, Gauthier G (1996) Ages of detrital zircon from ArcheanPaleoproterozoic sequences: Implications for Greenstone Belt setting and evolution of a Transamazonian foreland basin in Quadrilitero Ferrifero, southeast Brazil. Earth and Planetary Science Letters 141: 259-276

Matschullat J, Borba RP, Deschamps E, Figueiredo BF, Gabrio T, Schwenk M (2000a) Human and environmental contamination in the Iron Quadrangle, Brazil. Appl Geochem 15: 181-190

Matschullat J, Ottenstein R, Reimann C (2000b) Geochemical background - can we calculate it? Environ Geol 39, 9: 990-1000Matschullat J. \& Deschamps E (org). 2007. Arsênio Antropogênico e Natural: um Estudo em Regiões do Quadrilátero Ferrífero. 330 p. Fundação Estadual do Meio Ambiente - FEAM.

Mendes MAM (2007) Influência antrópica nas características hidrossedimentológicas e geoquímicas da bacia do Ribeirão Caraça, Quadrilátero Ferrífero, MG. Master thesis, Universidade Federal de Ouro Preto. Escola de Minas. Departamento de Geologia. Programa de Pós-graduação em Evolução Crustal e Recursos Naturais

Mendonça F P C (2012) Influência da mineração na geoquímica das águas superficiais e nos sedimentos no alto curso da bacia do ribeirão Mata Porcos, Quadrilátero Ferrífero - Minas Gerais Master thesis, Universidade Federal de Ouro Preto. Escola de Minas. Departamento de Geologia. Programa de Pós-graduação em Evolução Crustal e Recursos Naturais

Meneses I, Renger FE, Deschamps E (2011) History and socioeconomy - Iron Quadrangle. In:Deschamps E, Matschullat J (eds) Arsenic: natural and anthropogenic. Arsenic in the environment 4, 6: 73-80; CRC Press, Taylor and Francis, London

Nalini Jr. H. A. (coord). 2009. Estudos geoambientais no Quadrilátero Ferrífero: Mineração $e$ Sustentabilidade. Departamento de Geologia UFOP, Minas Gerais, $52 \mathrm{p}$

C. Neal, A.J. Robson (2000). A summary of river water quality data collected within the Land-Ocean Interaction Study: core data for eastern UK rivers draining to the North Sea. Sci. Total Environ., 251252 (2000), pp. 585-665.

Parra RR, Roeser HMP, Leite MGP, Nalini Jr HA, Guimarães ATA, Pereira JC, Friese K (2007) Influência antrópica na geoquímica de água e sedimentos do Rio Conceição, Quadrilátero Ferrífero, Minas Gerais - Brasil. Geochim Brasil 21, 1: 36-49

Pereira JC, Guimarães-Silva AK, Nalini Jr HA, Pacheco-Silva E, De Lena JC (2007) Distribuição, fracionamento e mobilidade de elementos traço em sedimentos superficiais. Quimica Nova 30, 5: 12491255

Ranasinghe PN, Fernando G W A R, Dissanayake CB, Rupasinghe MS, Witter DL (2009) Statistical evaluation of stream sediment geochemistry in interpreting the river catchment of high-grade metamorphic terrains. J Geochem Explor 103: 97114

Reimann C, Caritat P de (1998) Chemical elements in the environment. Factsheets for the geochemist and environmental scientist. Springer, Heidelberg; 398 p.

Reimann C \& Garrett RG (2005) Geochemical background-concept and reality. Sci Total Environ 350:12-27

Renger FE, Noce CM, Romano AW, Machado N (1994) Evolução sedimentar do Supergrupo Minas: $500 \mathrm{Ma}$ de registro geológico no Quadrilátero Ferrífero, Minas Gerais, Brasil. Geonomos 2, 1: 111

Roeser HMP, Friese K, Nalini Jr HA, Lena J, Parra RR (2007) Contaminação natural versus poluição antrópica em águas e sedimentos do NE do Quadrilátero Ferrífero, MG. In: Anais do XI Congresso Brasileiro de Geoquímica (CD-ROM). Atibaia, São Paulo, p. 4

Salminen, R., Chekushin, V., Tenhola, M., Bogatyrev, I., Glavatskikh, S.P., Fedotova, E., Gregorauskiene, V., Kashulina, G., Niskavaara, H., Polischuok, A., Rissanen, K., Selenok, L., Tomilina, O., Zhdanova, L., (2004). Geochemical Atlas of Eastern Barents Region. Elsevier, Amsterdam. 
Salminen R, Batista MJ, Demetriades A, Lis J, Tarvinen $T$ (2005) Sampling. In: Salminen R, Batista MJ, Bidovec M, Demetriades A, De Vito B, De Vos W, Duris M, Gilucis A, Gregorauskiene V, Halamic J, Heitzmann P, Lima A, Jordan G, Klaver G, Klein P, Lis J, Locutura J, Marsina K, Mazreku A, O'Connor PJ, Olsson SA, Ottesen RT, Petersell V, Plant JA, Reeder S, Salpeteur I, Sandstrom H, Siewers U, Steenfelt A, Tarvinen T Geochemical Atlas of Europe. Part 1 Background Information, Methodology and Maps. Geological Survey of Finland, Espoo

Smedley, P.L. \& D.G Kinniburgh, (2002). A review of the source, behaviour and distribution of arsenic in natural waters. Applied Geochemistry 17, 517-568

Smith DB, Smith SM, Horton JD (2012) History and evaluation of a national scale geochemical data set for the United States. Geosci Frontiers 4, 2: $167-$ 183

Thornton I (2012) Environmental geochemistry: 40 years research at Imperial College, London, UK / Applied Geochemistry 27: 939-953

Teixeira, W., Carneiro, M.A., Noce, C.M., Machado, N., Sato, K., Taylor, P.N., 1996. Pb, Sr and $\mathrm{Nd}$ isotope constraints on the Archaean evolution of gneissic-granitoid complexes in the southern São Francisco Craton, Brazil. Precambrian Res. 78, 151-164. doi:10.1016/0301-9268(95)00075-5

USEPA (2001) Sediment Sampling Guide and Methodologies. United States Environmental Protection Agency, Division of Surface Water. Columbus 2: 1-35.

U.S. Environmental Protection Agency, 2000, Drinking water standards and health advisories: U.S. Environmental Protection Agency, Office of Water, EPA-822-B-00-001. Last access May 21, 2018.

http://www.epa.gov/waterscience/drinking/standard s/index.html

Varejão, E. V., Bellato, C. R., Fontes, M. P. F., Mello, J. W. V. Arsenic and trace metals in river water and sediments from southeast portion of Quadrilátero Ferrífero, Brazil. Environmental Monitoring Assessment, v. 172, p. 631-642, 2010.

World Health Organization (2004) Guidelines for drinking-water quality, Volume 1.

Recommendation, for water supplies $3^{\text {nd }}$ edition, WHO, Geneva, Switzerland. 